\title{
Pelagic habitats in the Mediterranean Sea: A review of Good Environmental Status (GES) determination for plankton components and identification of gaps and priority needs to improve coherence for the MSFD implementation
}

\author{
Varkitzi I. ${ }^{1,{ }^{*}}$, Francé J. ${ }^{2}$, Basset A. ${ }^{3}$, Cozzoli F. ${ }^{3}$, Stanca E. ${ }^{3}$, Zervoudaki S. ${ }^{1}$, Giannakourou A. ${ }^{1}$, \\ Assimakopoulou G. ${ }^{1}$, Venetsanopoulou A. ${ }^{1}$, Mozetič P. ${ }^{2}$, Tinta T. ${ }^{2,4}$, Skejic S. ${ }^{5}$, Vidjak O. ${ }^{5}$, \\ Cadiou Jean-Francois ${ }^{6}$, Pagou K. ${ }^{1}$
}

\footnotetext{
${ }^{1}$ Hellenic Centre for Marine Research HCMR, Institute of Oceanography, Anavyssos, 19013 Attica, Greece

${ }^{2}$ Marine Biology Station, National Institute of Biology, Fornače 41, Piran 6330, Slovenia

${ }^{3}$ University of Salento, Department of Biological and Environmental Sciences and Technologies, S.P. Lecce-Monteroni - Ecotekne, Lecce 73100, Italy

${ }^{4}$ Department of Limnology and Bio-Oceanography, Center of Functional Ecology, University of Vienna, Althanstraße 14, Vienna 1090, Austria

${ }^{5}$ Institute of Oceanography and Fisheries, Šetalište I. Meštrovića 63, Split 21000, Croatia

${ }^{6}$ Institut Français de Recherche pour l'Exploitation de la Mer IFREMER, European and International

Affairs Department, Zone Portuaire de Bregaillon CS 20 330, La Seyne-sur-Mer 83507, France
}

* Corresponding author : I. Varkitzi, email address : ioanna@hcmr.gr

\begin{abstract}
:
At present there is no consistent approach for the definition of Good Environmental Status (GES) and targets in the Mediterranean Sea, especially for Biodiversity Descriptors, according to the Article 12 of the Marine Strategy Framework Directive (MSFD). The use of plankton indicators in the Mediterranean Sea refers mostly to pelagic habitats in coastal waters and to case studies connected with environmental pressures, e.g. in the Adriatic, Aegean etc. The aim of this review is to study the existing biodiversity indicators for different plankton groups in order to compare GES definitions for the Biodiversity Descriptor and identify the relevant gaps and priority needs to improve coherence for the MSFD implementation across the Mediterranean. For these purposes, we focus on plankton indicators for phytoplankton, zooplankton and prokaryotes. Regional conventions (OSPAR, HELCOM, Barcelona and Bucharest Conventions) have long considered phytoplankton as a key element for integrated assessment systems. Phytoplankton biomass, community composition, abundance, frequency and intensity of blooms are used for such assessment purposes. Chlorophyll a still remains the most widely used indicator mostly thanks to its time saving, cost-effective and reproducible analytical methods that provide easily comparable datasets. Despite some integrated indices proposed for phytoplankton in the literature at the Mediterranean level, a number of constrains still prevent their wide use. Regarding zooplankton communities, commonly used indicators have a taxonomic base while recently size structure and biomass can provide a valuable index of zooplankton population dynamics and ecosystem production. Jellyfish blooms' occurrence and frequency are also considered important zooplankton
\end{abstract}


indicators in specific areas, e.g. North Adriatic. Concerning the prokaryotes, so far MSFD takes into account only their pathogenic component. The revision of MSFD GES definitions shows that all Mediterranean MSs have defined GES at the Descriptor level (e.g. D1 Biodiversity), but our comparison of approaches shows a low level of coherence in GES related to pelagic habitats and plankton communities. Gaps mostly focus on the lack of thresholds and baselines for many biodiversity indicators, and on the scarcity of common and consistent methodological approaches for biodiversity assessment by the MSs. Suggestions to fill these gaps and inconsistencies among MSs include: integration of EU legislation and Regional Agreements and Conventions; targeting on priority species and habitats; testing of existing biodiversity indices with good performances in case studies; coordination and intercalibration actions for the establishment of threshold values and baselines; determination of common methodologies; undertaking of regular monitoring programs and impact assessment studies at regional and sub-regional levels.

\section{Highlights}

- Low coherence for GES definitions in Mediterranean plankton communities was found. Phytoplankton is a key element for assessment systems of MSFD and Regional Conventions. GES targets are based only on Chlorophyll a thresholds in the Mediterranean so far. Quantitative GES targets for zooplankton in Mediterranean exist only in Slovenia. Gaps mostly focus on lack of thresholds and baselines for many biodiversity indicators.

Keywords: Plankton indicator, s Pelagic habitats, Biodiversity, Mediterranean sea, MSFD, GES assessment 
The ancient Greek word Pelagos, found in Homer's epics, refers to the open sea. The pelagic realm spans through the whole water column and it is the largest ecosystem on Earth (Kaiser et al., 2011). It can be subdivided by the water depth and the distance from shore to the neritic zone, defined as the ocean part within the continental shelf, and to the oceanic zone off the continental shelf. However, the term "pelagic habitat" as used by the Marine Strategy Framework Directive (MSFD 2008/56/EC), relates to the whole pelagic realm, as also delineated by Würtz (2010) in his overview of the Mediterranean pelagic habitats. The Annex 1 of the guidelines for reporting under the MSFD (European Commission, 2012) includes the reference and term lists, which represents a simplified version of the EUNIS classification for the category "water column habitats", with the following divisions: i) Reduced salinity water; ii) Variable salinity (estuarine) water; iii) Marine water: coastal; iv) Marine water: shelf; and v) Marine water: oceanic.

The Mediterranean is the largest European semi-enclosed sea. It has heterogeneous topography, with narrow continental shelf, average depth of approx. $1600 \mathrm{~m}$ and highly complex water circulation (Bergamasco and Malanotte-Rizzoli, 2010). Although it is a shallow sea compared to the oceans, a large part of the Mediterranean can be considered as a deep sea, given that several areas reach and exceed $4000 \mathrm{~m}$ depth (Coll et al., 2010). The Mediterranean pelagic realm is thus a highly variable four-dimensional structure (Würtz, 2010). All these peculiarities of the Mediterranean pelagial are reflected in the structure and dynamics of the plankton communities (Siokou-Frangou et al., 2010).

The Mediterranean Sea is generally oligotrophic, with increasing nutrient limitation from west to east, mostly as phosphorus limitation. This feature leads to a heterogeneous distribution of primary production and to a decreasing west-east gradient in chlorophyll $a$ concentrations (D'Ortenzio and Ribera d'Alcalà, 2009). There are, however, some areas with higher chlorophyll a concentrations, which are in coastal waters generally related to river inputs (e.g., western part of the Northern Adriatic, Mangoni et al., 2008; Zoppini et al., 2010, 1995), while there are more connected to air-sea interactions in the open seas. The Mediterranean Sea is generally well oxygenated, which is true also for its deep layers (Siokou-Frangou et al., 2010).

The biodiversity of the Mediterranean Sea is very high, reflecting the wide range of climatic and hydrological conditions that allowed for the survival of both temperate and subtropical organisms, primarily originating from the Atlantic Ocean, and with a high percentage of endemic species (Coll et al., 2010). An important bulk of species diversity is attributed to the prokaryotic (Bacteria and Archaea) and eukaryotic (Protists) marine microbes (as reviewed in Luna, 2015 and Sunagawa et al., 2015). Diversity of several microbial groups can be accurately and readily recognized under the optical microscope (e.g. diatoms, dinoflagellates, coccolithophores and silicoflagellates among phytoplankton, and tintinnids, foraminifers and radiolarians among microzooplankton)(Kršinić, 2010; Kršinić and Kršinić, 2012), however the taxonomic determination of a plethora of marine microorganisms requires application of cultureindependent molecular-based methods. Much less is known about groups of auto- and 
heterotrophic nanoflagellates and picoplankton species (Coll et al., 2010). Molecular methods and next generation sequencing tools/platforms, which are growingly applied to uncover microbial diversity, are promising tools that will help to assess the status of the pelagic habitats in a more accurate, rapid and on a long term even less expensive manner also in the Mediterranean Sea in the nearby future.

In the last decades, plenty of Mediterranean Sea plankton investigations were first oriented towards phyto- and zooplankton biomass and structure of plankton communities (species composition, abundance and seasonal distribution), and later included also the heterotrophic components of the pelagic food web and biological processes (reviewed by Siokou-Frangou et al., 2010). Literature oriented towards the assessment of the environmental status with the use of plankton indicators is far scarcer, especially those related to the open waters of the Mediterranean Sea.

So far plankton indicators mostly refer to Mediterranean coastal waters with specific case studies, e.g. in the Adriatic and the Aegean, and their development is always connected to environmental pressures (Markogianni et al., 2017; Ninčević Gladan et al., 2015; Spatharis and Tsirtsis, 2010; Varkitzi et al., in press). The environmental status of the pelagic habitat is addressed in the Biodiversity Descriptor 1 (D1) of the MSFD, for which the new Commission Decision 2017/848/EU sets one primary Criterion (D1C6). The condition of this habitat type is considered as a whole of its biotic and abiotic characteristics and its functions. In this review, we focus on the plankton indicators drawing attention to phytoplankton, zooplankton and prokaryotes. The aim of this study is to review the existing biodiversity indicators for different plankton groups in order to compare the Good Environmental Status (GES) definitions for the Biodiversity Descriptor and identify the relevant gaps and priority needs to improve coherence for the MSFD implementation across the Mediterranean. We also refer to other European Seas for reasons of comparison of available plankton indicators.

\section{Existing approaches for the determination of GES and targets}

There is no consistent approach for the definition and assessment of GES and targets in the Mediterranean in relation to MSFD Descriptors' (Fig. 1), and this is most obvious in the case of biodiversity descriptors (Paramana et al., 2017). Altogether, the number of biodiversity indicators catalogued for European Seas by the Devotes project (DEVOTool, Teixeira et al., 2016, 2014 ) is quite high for phytoplankton, benthic invertebrates and fish. However, a high number of those phytoplankton indicators remain at a non-operational level (in conceptual phase or under development) or without any status assigned, despite the fact that most of them were expected to be operational already, as they were parts of the Water Framework Directive (WFD) assessment (Teixeira et al., 2014). 


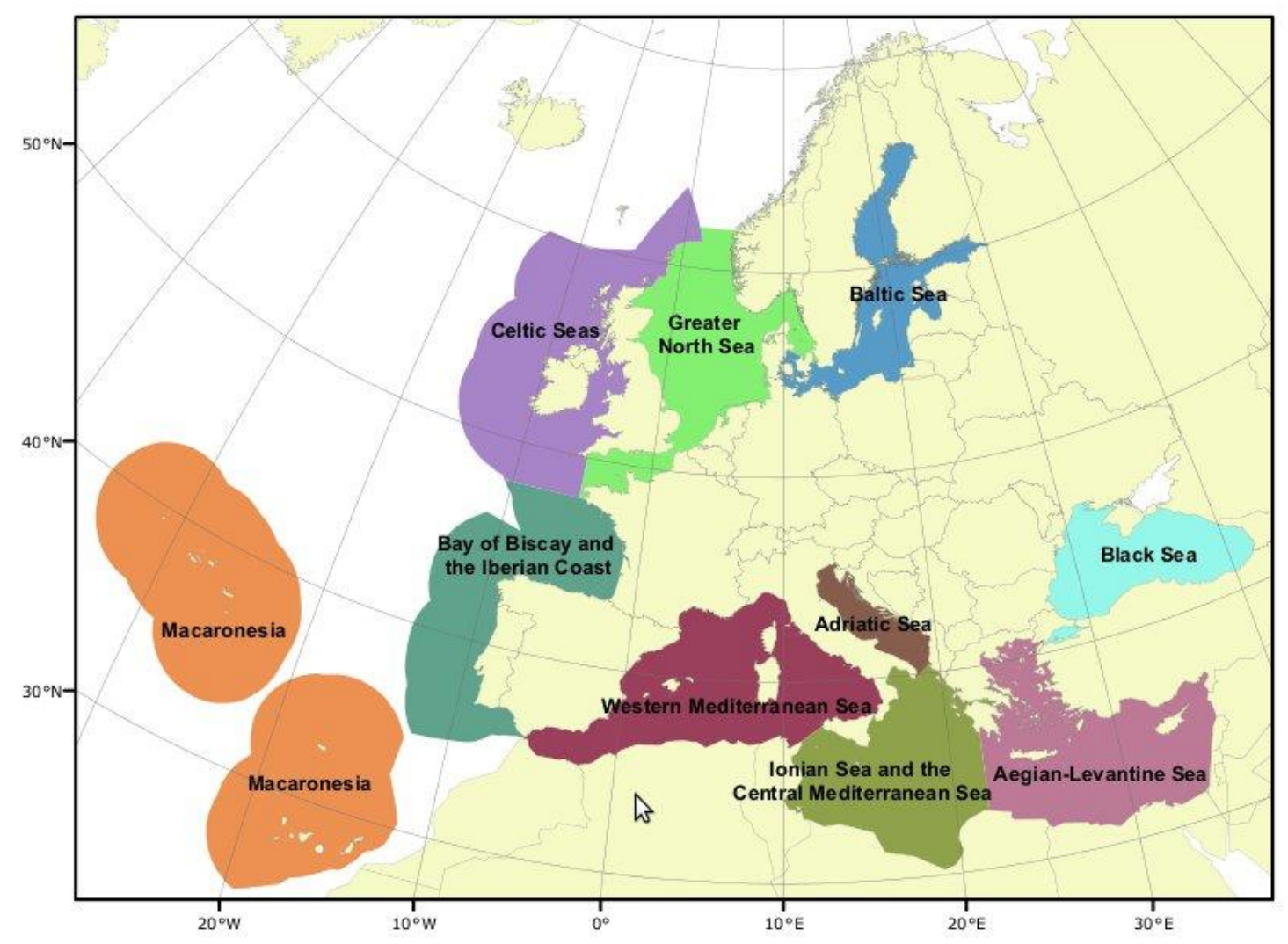

134 Fig. 1. Sub-regions in the Mediterranean and other European seas which are covered by the 135 Marine Strategy Framework Directive (source: www. emodnet-chemistry.eu).

\subsection{Review of phytoplankton indicators}

The WFD (2000/60 EC), which establishes a framework for the protection of all European waters, was the first to have addressed systematically and Europe-wide the biotic components of water habitats. In the case of coastal waters, the biological quality element used for the assessment of the ecological status in the pelagic habitat is phytoplankton. Phytoplankton parameters to be used for this assessment are biomass, community composition and abundance, as well as frequency and intensity of blooms. Several attempts have been made to develop an integrated assessment of ecological quality of coastal waters based on more than one of these attributes in different European regions, where phytoplankton has long been considered in the assessment systems required by regional conventions, such as OSPAR, HELCOM, Bucharest and Barcelona conventions.

A variety of phytoplankton indicators can be found in the scientific literature, web-pages, different projects' reports and deliverables, which have been developed and/or used at the Mediterranean Sea level, all aiming to assess the status of the marine environment. The use of a combination of multiple phytoplankton related parameters is encouraged by the scientific community and it has been made mandatory in European Directives. Although some integrated indices have been proposed in the literature by different groups of experts at the Mediterranean Sea level (e.g. Pachés et al., 2012; Romero et al., 2013; Spatharis and Tsirtsis, 2010), a number of constrains still prevent the wide use of these assessment systems, especially at the operational level. The methods used to analyse phytoplankton communities are mainly based on time consuming cell counts. This dictates a trade-off between the number of samples in a monitoring 
plan and the financial budget, the available personnel and the response time (Cozzoli et al., 2017).

160

161

162

163

164

165

166

167

168

169

170

171

172

173

174

175

176

177

178

179

180

181

182

183

184

185

186

187

188

189

190

191

192

193

194

195

196

197

198

199

200

201

202

203

204

205

206

207

Phytoplankton community composition in coastal waters is in general seasonally and interannually highly variable, lacking a direct relationship to nutrient status of the water body (Pugnetti et al., 2007). Taking into account the wide range of cell dimensions, phytoplankton biomass can be greatly underestimated or overestimated. To overcome this constrain, carbon biomass or biovolume can be used (Cozzoli et al., 2017) although data-series containing one of these parameters are extremely rare in coastal waters.

On the other hand, the use of chlorophyll $a$ as a status indicator has a lot of advantages: both spectrophotometric and fluorimetric analytical methods are time and cost-effective and reproducible, while the results are easily comparable among datasets (Domingues et al., 2008); the sensitivity of chlorophyll $a$ to nutrient concentrations in the water column is well documented (Håkanson and Eklund, 2010; Harding et al., 2013; Mozetič et al., 2012). It is therefore not surprising, that chlorophyll $a$ datasets are among the most widely used in the assessment systems (Giovanardi et al., 2018; Höglander et al., 2013). However, there are also some disadvantages of the use of chlorophyll $a$, e.g. the non-linear relationship between chlorophyll $a$ concentration and species biomass expressed in carbon content due to environmental factors and interspecific differences (Kruskopf and Flynn, 2006) or shifts in the baselines due to other pressures related to global change (Carstensen et al., 2011).

Biodiversity core indicators program of HELCOM evaluates the status of the Baltic Sea as reflected by plankton communities along with other biological parameters (benthic biotopes, fish etc). The core indicators are commonly agreed tools to follow the progress towards the Baltic Sea Action Plan overall goal of achieving GES in the Baltic by 2021. In the Baltic region, chlorophyll $a$ is the only phytoplankton parameter taken into account together with nutrient concentrations, water transparency and oxygen debt in the Eutrophication Assessment Tool (HEAT 3.0), that complies with WFD requirements (Fleming-Lehtinen et al., 2015). In the recent HELCOM pre-core indicator report for Biodiversity, the Diatom/Dinoflagellate index (Dia/Dino index) was included as a test indicator for the purposes of the mid-2017 'State of the Baltic Sea' report (HELCOM 2017a). This phytoplankton indicator reflects the dominance patterns in the phytoplankton spring bloom, it is connected with the food pathway into pelagic or benthic food webs and it is applicable in all coastal and open sea assessment units with few exceptions. It is primarily a descriptive trend indicator for changes in the food web but it may also indicate the eutrophication effect of silicate limitation. This indicator's results are to be considered as in intermediate progress and the threshold values are yet to be commonly agreed in HELCOM. Other phytoplankton biodiversity indicators under development by HELCOM are "Seasonal succession of functional phytoplankton groups" (candidate), "Phytoplankton community composition as a food web indicator" (candidate), "Phytoplankton species assemblage clusters based on environmental factors" (candidate) and "Phytoplankton taxonomic diversity (candidate)" (HELCOM 2017b).

Two phytoplankton parameters are used to assess the status of waters with regard to anthropogenic eutrophication in the North-East Atlantic region using OSPAR Comprehensive Procedure: chlorophyll $a$ concentrations and elevated levels of HAB indicator species (Foden et al., 2011). In the Black Sea region all WFD recommended phytoplankton parameters are in use for the assessment of the ecological status of Romanian and Bulgarian coastal waters with Integrated Biological Index (IBI) - Phytoplankton (Carletti and Heiskanen, 2009), which was based on the work of Spatharis and Tsirtsis (2010).

In the WFD Mediterranean Geographical Intercalibration Group (Med-GIG) there has been a wide discussion on the use of different phytoplankton attributes for the assessment of the ecological quality of coastal waters. Finally, the European Commission (EC) Decision 2013/480/EU considered chlorophyll $a$ as the only classification criterion for Biological Quality 
Element (BQE) Phytoplankton. Reference conditions and boundaries between the Good and Moderate Ecological Classes have been based on chlorophyll $a$ concentrations in different coastal water typologies, and they are presented in Table 1 . This classification system has been incorporated in the recent EC Decision 2018/229/EU, which repeals the previous EC Decision 2013/480/EU and establishes the values of the MS monitoring system classifications as a result of the intercalibration exercise, pursuant to Directive 2000/60/EU. The MSs that participated in the Med-GIG and currently follow this classification system are Croatia, Cyprus, Greece, France, Italy, Slovenia and Spain.

Table 1: Water types, reference conditions and boundaries in the Mediterranean coastal waters for chlorophyll $a$ concentrations (parameter used as a proxy of phytoplankton biomass) according to the WFD Mediterranean Geographical Intercalibration Group (Med-GIG). (Source: ANNEX to the European

220 Commission Decision 2018/229/EU).

\begin{tabular}{|c|c|c|c|c|c|}
\hline \multirow[t]{2}{*}{$\begin{array}{l}\text { Coastal water } \\
\text { types }\end{array}$} & \multirow[t]{2}{*}{$\begin{array}{l}\text { Coastal water typology } \\
\text { criteria }\end{array}$} & \multicolumn{2}{|c|}{$\begin{array}{l}\text { Reference conditions of Chl-a } \\
\left(\mu \mathrm{g} \mathrm{L}^{-1}\right)\end{array}$} & \multicolumn{2}{|c|}{$\begin{array}{l}\text { Good/Moderate Boundaries of Chl-a } \\
\left(\mu \mathrm{g} \mathrm{L}^{-1}\right)\end{array}$} \\
\hline & & geometric mean & 90-percentile & geometric mean & 90-percentile \\
\hline Type I & $\begin{array}{l}\text { Type I: highly influenced by } \\
\text { freshwater inputs, } \\
\text { salinity }<34.5\end{array}$ & 1.40 & $3.33-3.93$ & 6.30 & $102.00-17.73$ \\
\hline $\begin{array}{l}\text { Type II-FR-SP } \\
\text { (France-Spain) }\end{array}$ & $\begin{array}{c}\text { Type II: not directly } \\
\text { affected by freshwater } \\
\text { inputs, } 34.5<\text { salinity }<37.5\end{array}$ & - & 1.90 & - & 3.58 \\
\hline $\begin{array}{l}\text { Type II-A Adriatic } \\
\text { Sea }\end{array}$ & $"$ & 0.33 & 0.8 & 1.50 & 4.00 \\
\hline $\begin{array}{l}\text { Type II-A } \\
\text { Tyrrhenian Sea }\end{array}$ & $"$ & 0.32 & 0.77 & 1.20 & 2.90 \\
\hline $\begin{array}{l}\text { Type III-W } \\
\text { Adriatic Sea }\end{array}$ & $\begin{array}{l}\text { Type III: not affected by } \\
\text { freshwater inputs, } \\
\text { salinity }>37.5 \\
\end{array}$ & - & - & 0.64 & 1.70 \\
\hline $\begin{array}{l}\text { Type III-W } \\
\text { Tyrrhenian Sea }\end{array}$ & " & - & - & 0.48 & 1.17 \\
\hline $\begin{array}{l}\text { Type III-W FR-SP } \\
\text { (France-Spain) }\end{array}$ & $"$ & - & 0.90 & - & 1.80 \\
\hline Type III-E & " & - & 0.20 & - & 0.53 \\
\hline Type Island-W & " & - & 0.60 & - & $1.20-1.22$ \\
\hline
\end{tabular}

At the regional level, the number of phytoplankton indicators is the lowest for the

Mediterranean Sea as compared to other European Seas (Teixeira et al., 2016; 2014). Higher numbers of phytoplankton indicators mainly reflect larger research efforts and data collection in the North-East Atlantic Ocean (twenty two indicators addressing only phytoplankton or more biodiversity components; Uusitalo et al., 2016) and/or greater development and implementation of indicators in more eutrophied seas, such as Baltic and Black Seas. There are three operational indicators in the Baltic Sea, addressing exclusively phytoplankton and eight operational that include phytoplankton with other components. In the Black Sea most of the biodiversity indicators are relevant to phytoplankton (seven are operational) and benthic invertebrates as well.

A search for the Mediterranean Sea within the DEVOTool catalogue (Teixeira et al., 2016, 2014) shows that there is one biodiversity indicator exclusively addressing phytoplankton under development and one without status in the Mediterranean Sea, while there are seven that address phytoplankton together with other biodiversity components (five are operational, one is under development and one is without status). For Eastern Mediterranean there is only one operational phytoplankton indicator with the biodiversity component, i.e. Pielou evenness Index. 
addressed. Therefore, it is very difficult to compare and conclude about large scale seasonal and spatial patterns and cycles. Another aspect to be considered is the connection of phytoplankton indicators with the associated habitat types, as also for zooplankton, macroalgae, angiosperms and benthic invertebrates (MSFD Task Group 1 Report, Teixeira et al., 2014). In the context of the keystone species approach (according to the MARBEF definition and Menge et al. 2013), taxon specific indicators are considered important (at genus or species level). However, there are no taxon specific indicators for phytoplankton (together with microbes), unlike zooplankton (biomass of ctenophore Mnemiopsis leidyi), phytobenthos (depth distribution of Posidonia oceanica) and other biological elements (Smith et al., 2014).

In the frame of the WISER and ActionMed projects, Cozzoli et al. (2017) tested some commonly used indices/metrics for the description of phytoplankton communities and showed that some metrics are strongly dependent upon the sampling effort (as number of enumerated individuals per sample), while others are relatively independent. Actually they found a large heterogeneity in metrics response to the sampling effort intended as number of counted individuals per phytoplankton sample. Size-related metrics $\left(I V D_{\text {mean }}\right.$ ', ISS-phyto $)$, being characterised by high precision and low uncertainty, could generally provide greater accuracy than taxonomic metrics to describe the community and are able to reach an acceptable accuracy at sample sizes lower than 200 counted individuals. Size-related metrics have also the advantages of being sensitive to environmental stress (Lugoli et al., 2012; Sabetta et al., 2008; Vadrucci et al., 2013), minimising the problem of taxonomic expertise required, and allowing quantitative inter-calibration procedures (Carvalho et al., 2013).

Dominance metrics present similar accuracy to that of the size-related metrics (Cozzoli et al., 2017). In particular, the Berger-Parker's dominance index proved to be an efficient metric, with special focus only on the easily identifiable most abundant taxa and, as other dominance indices (Facca and Sfriso, 2009) it is sensitive to environmental conditions. Therefore, Cozzoli et al. (2017) suggest that the use of size (as it is in ISS-phyto') and dominance (as it is in MPI') metrics, alone or combined in multimetric indices, could be an efficient approach for operational monitoring implementation, able to maximize the precision and minimize the uncertainty of estimates. According to this work, these metrices can produce reliable environmental assessments by using a sampling effort (in terms of counted individuals per sample) $50 \%$ lower than the 400 cells required from the most used international standard.

\subsection{Use of Harmful Algal Blooms (HABs) in assessment systems}

Some species of phytoplankton are considered as key elements to monitor the marine environment in certain cases, e.g. when they produce harmful algal blooms (HABs). In the European context, Ferreira et al. (2011) recommended that, if, but only if, HAB frequency, amplitude, or toxicity increase in response to nutrient inputs, then HABs should be treated as one of the MSFD indicators of eutrophication.

Phytoplankton blooms play a central role as ecological/environmental status assessment traits of high policy importance for WFD and MSFD. However, one of the main challenges in their practical application is the need of data with frequency corresponding to the spatial and temporal scales of phytoplankton variability. So far there are no operational indicators for HABs related to D1 in the Mediterranean MSs (Cozzoli et al., 2016). In parallel to the approach of Ferreira et al. (2011), HAB related indicators could only be operational for D1 if occurrence and extent of HAB species prove to be connected in a significant manner with the status of biodiversity in a certain habitat. 
contain potentially toxic algae, such as Pseudo-nitzschia spp. (Garcés and Camp, 2012). On the contrary, blooms of (potentially) harmful algae are occurring frequently in Mediterranean coastal waters. Garcés and Camp (2012) list some "hot spot" regions, such as Alboran, Ligurian, Adriatic and Aegean Seas. These can be high biomass blooms or toxic blooms, which can both have deleterious effects of coastal waters biodiversity. These authors suggest one possible connection of HABs to D1, related to habitat change, for example the substantial modifications of the Mediterranean Catalan coastline have created more confined waters and led to the increase of HAB events over the last 50 years. Substantial degradation or alteration of coastal habitat may thus alter the biodiversity also through changes in HAB phenomena.

In a recent study that deals with port environments across the Adriatic Sea, Mozetič et al. (2017) found $52 \mathrm{HAB}$ taxa, among them also some toxigenic non-native phytoplankton species with possible invasive character (Pseudo-nitzschia multistriata, Ostreopsis sp. and $O$. cf. ovata). Given the species found most frequently (Dinophysis caudata, D. sacculus, D. fortii, Phalacroma rotundatum, Alexandrium species, Lingulodinium polyedrum and Pseudo-nitzschia species), accumulation of toxins in seafood is the most expected harmful effect in the Adriatic Sea, but fish killings and high biomass blooms are also expected to occur (Mozetič et al., 2017). In coastal areas of Eastern Mediterranean, toxic microalgal Dinoflagellates of the "Dinophysis acuminata complex" have been mostly responsible for Mytilus galloprovincialis intoxications over the last fifteen years (Thermaikos Gulf, north Greece, see Koukaras and Nikolaidis, 2004; Varkitzi et al., 2013). Pseudo-nitzschia delicatissima and P. multiseries are frequent potentially toxic Diatoms, Alexandrium tamarense, A. minutum and Dinophysis caudata are other most frequent potentially toxic Dinoflagellates, and Chaetoceros spp., Skeletonema costatum and Prorocentrum micans are among the frequent high biomass producers (Maliakos Gulf, central Greece, see Varkitzi et al., in press). These coastal areas are affected by riverine inputs, high pollution levels and eutrophication.

Similar harmful species checklists resulted also from a study of HABs in the Tyrrhenian Sea (Zingone et al., 2006), from reviews of HABs in Greek coastal waters (Ignatiades and GotsisSkretas, 2010) and NW Mediterranean Sea (Vila and Maso, 2005). In some areas there is also a considerable impact of high biomass blooms, which cause discoloration of waters. They are mainly caused by dinoflagellates (Noctiluca scintillans, Prorocentrum and Alexandrium species), Phaeocystis species, Vicicitus globosus and some Prasinophytes (e.g. Ignatiades and GotsisSkretas, 2010, Zingone et al., 2006).

Within the scope of the OSPAR Eutrophication Strategy for the North-East Atlantic, nine Contracting Parties applied the OSPAR Common Procedure in 2017, using data from 2006 to 2014 (OSPAR, 2017). The elevated levels of nuisance/toxic phytoplankton indicator species and the increased duration of blooms were used as eutrophication assessment parameters by seven out of nine Contracting Parties. The nuisance species included the foam-forming species Phaeocystis or the dense surface blooms of Noctiluca as indicator species. The abundance of Phaeocystis spp. had already been developed as an OSPAR common indicator for the southeastern North Sea in a previous stage. However, the Contracting Parties have assigned different importance to phytoplankton indicator species and algal toxins as indicators for eutrophication, and this has led to differences in their use. The application of toxic phytoplankton species was questioned, suggesting that the link to anthropogenic nutrient enrichment has been found to be insufficient to guarantee continuous use in some cases, e.g. in the Sea of Scotland and the southern North Sea HABs have been linked to large hydrodynamic movements and climatic conditions (Davidson et al., 2014; Gieskes et al., 2007). Therefore a more general approach is favored by the United Kingdom, involving the use of an index for application in WFD assessments, instead of using single phytoplankton species.

337 There is a list of over 60 species of potentially harmful phytoplankton in the Baltic Sea with 338 connection to toxicity, mechanical disturbance, bloom formation and water coloration (Ojaveer 339 et. al., 2010). However, there are no biodiversity indicators related to nuisance/toxic 
phytoplankton species that are currently being developed by HELCOM. Instead, there is the Cyanobacterial bloom index (HELCOM 38-2017; Kaitala and Hällfors, 2008) that integrates the rank abundance of only the two main bloom forming and nitrogen fixing cyanobacteria Aphanizomenon flos-aquae and Nodularia spumigena during the whole growth season in the Baltic Sea (Laamanen and Kuosa, 2005). There are also three other indices developed to compare cyanobacteria blooms between different years, i.e. the bloom normalized duration ( $\mathrm{T}$ ), extent (A) and intensity (I) (Hansson and Hakansson, 2007; Öberg, 2016). In the Black Sea about 20 species are listed as potentially toxic, but only few cases of toxicity have been reported (Alexandrov et al., 2012; Bargu et al., 2002; Vershinin et al. 2005). The harmful effects are associated mainly to hypoxic conditions during bloom events there (Black Sea Commission, 2008).

\subsection{Review of zooplankton indicators}

Information on the zooplankton communities, including the species composition/distribution and seasonal/geographical variability, provide a relevant contribution to the definition of GES for various MSFD Descriptors (e.g. D1, D2 and D4). There is considerable scientific and practical interest in understanding how the biological components of marine systems respond to both single and multiple stressors. The response of zooplankton to environmental conditions is of particular interest due to the central and mediating role that this group occupies as a trophic link between planktonic primary producers and larger consumers. Consequently, any variation in zooplanktonic biomass and species composition has implications on biogeochemical cycling, trophic dynamics, fisheries and other ecosystem services. For example, target zooplankton organisms are important trophic links to many commercially and recreationally important fish species, as demonstrated in several case studies from NW Med, SW Med, Adriatic Sea and Aegean sea (E Med) (Bacha and Amara, 2009; Borme et al, 2009; Nikolioudakis et al., 2012; Palomera et al, 2007).

Zooplankton as GES indicator can include various levels of complexity, ranging from rather reductionist to holistic indicators, integrating a broad range of environmental information. In general, in marine coastal ecosystems, the plankton community is often characterized by a pronounced degree of unpredictability, a feature that hinders the definition of the baselines necessary to identify a Threshold Value for the definition of GES (HELCOM, HOD 48-2015). Long term changes in total abundance, biomass, species composition and community structure can be used as representative of environmental changes in the pelagic compartment and of potential impacts related to anthropogenic pressures, such as nutrient enrichment or oil spills (HELCOM, 2012).

Certain metrics for zooplankton communities have been emerging as valuable indices for population dynamics. Zooplankton community metrics are functions of changing natural environmental factors and respond to a gradient of mixed anthropogenic pressures. These metrics have been traditionally based on the taxonomic structure (biodiversity indices) while recently size structure and biomass are more frequently used to provide a valuable assessment of zooplankton population dynamics and ecosystem production. The development of indicators is based mainly on the following zooplankton attributes: total abundance, total biomass, copepod abundance, \% copepod abundance, copepod biomass, \% copepod biomass (since copepods is the most abundant group in the mesozooplankton community), microphagous species biomass, \% microphagous species biomass, cladocerans/copepods ratio, rotifers+cladocerans/copepods ratio, zooplankton mean size. There are more zooplankton indicators in use in other European Seas in comparison to the Mediterranean Sea, mostly due to larger research efforts and long history of data collection, as in the case of phytoplankton (Serranito et al., 2016; Uusitalo et al., 2016). 
Biodiversity indices. Given the large number of indices, it is often difficult to decide which the best method to measure diversity is. A method of selecting a diversity index is on the basis of whether it fulfils certain functions criteria - ability to discriminate between sites, dependence on sample size, what component of diversity is being measured, and whether the index is widely used and understood. The selection of indicators, namely evenness, species richness and biodiversity indices, has been made mostly according to the rational proposed by Southwood and Henderson (2000) and Magurran and Mc Gill (2011).

Size and biomass related indices. During the first reporting period of the MSFD, attempts have been made to include zooplankton and jellyfish in the assessment of the Slovenian marine waters (Orlando Bonaca et al., 2012a, b, c). The two functional groups - elements were considered in the frame of D4 Food webs and D1 Biodiversity (Criterion 1.6) of pelagic habitats for the initial assessment and GES definition. Slovenia reported quantitative baseline and thresholds for zooplankton and only qualitative for jellyfish. To assess the environmental status based on zooplankton, the annual geometric mean of mesozooplanktonic biomass was used as the metrics. The threshold between Good/Not Good status was defined on the basis of the multiannual geometric mean of the reference period for the Gulf of Trieste (northern Adriatic). The reference conditions were based on analyses of the zooplankton biomass derived from surveys made by Italian, Croatian and Slovenian researchers between 1971 and 1981 (Benović et al, 1984); which is regarded to as the period before the main eutrophication period and before the overfishing of pelagic fish in the northern Adriatic Sea occurred. As for jellyfish, the initial assessment was based on the nearly 200-year data series on the presence of Scyphozoans jellyfish in the northern Adriatic, with an emphasis on data about the occurrence of the moon jelly (Aurelia aurita). The periodicity of jellyfish occurrence was assessed with wavelet analysis (Kogovšek et al, 2010), which was then used to define the qualitative threshold for GES.

In HELCOM region, zooplankton is also included in core indicators for biodiversity (HELCOM, 2017c). Zooplankton mean size has declined in most areas of the Baltic Sea since 1980s, as a result of both the increase of the biomass of small zooplankton taxa - as a consequence of eutrophication (Uye, 1994) - and the decrease of the copepods' biomass - as a consequence of higher predation by zooplanktivorous fish (sprat and herring) and/or altered environmental conditions, e.g. decreased salinity, increased temperature and deep water hypoxia (Gorokhova et al., 2016). To quantify these changes, the mean zooplankter size (MeanSize) presented as a ratio between the total zooplankton abundance (TZA) and total biomass (TZB), is proposed as one metrics in the core indicator for food web structure. This metrics is complemented with an absolute measure of total zooplankton stock, TZA or TZB, to provide a two-dimensional index, MSTS (Mean Size and Total Stock). MSTS represents a synthetic descriptor of zooplankton community structure (by MeanSize) and the stock size (by TZA or TZB). Indeed, abundant zooplankton with high mean individual size would represent both favourable fish feeding conditions and high grazing potential, whereas all other combinations of zooplankton stock and individual size would be suboptimal and imply food web limitations in terms of energy transfer from primary producers to higher trophic levels and poorer food availability for planktivorous fish (HELCOM, 2017b).

\section{4: The Barcelona Convention for phytoplankton and zooplankton indicators}

One of the important MSFD demands is that MSs cooperate and coordinate the actions using the regional sea conventions. The Convention for the Protection of the Marine Environment and the Coastal Region of the Mediterranean (Barcelona Convention) was established in 1976 and at present comprises 22 Contracting Parties. In this way it consolidates the activities in European Community MSs and other Mediterranean countries. 
In 2016 the Barcelona Convention adopted the Integrated Monitoring and Assessment

438 Programme of the Mediterranean Sea and Coast and Related Assessment Criteria (IMAP)

439 (UNEP/MAP, 2017). IMAP describes the strategy, themes, and products that the Contracting

440 Parties are aiming to deliver over the second cycle of the implementation of the Ecosystem

Approach Process (EcAp process 2016-2021), in order to assess the status of the Mediterranean Sea and coast. One of the main outcomes of this process is that IMAP covers the Ecological Objectives related to Biodiversity (E01) in accordance with D1 of MSFD. Among the existing five Biodiversity common indicators, there are only two related to pelagic habitats, namely the Common indicator 1: Habitat distributional range (E01) to also consider habitat extent as a relevant attribute, and the Common indicator 2: Condition of the habitat's typical species and communities (E01).

To provide representative sites and species to include in the monitoring programs, a reference list of species and habitats is presented in Annex 1 of the IMAP document (UNEP/MAP, 2017). The Contracting Parties need to include the monitoring of the reference list species and habitats within at least two monitoring areas in their national monitoring programmes, one in a low pressure area and one in a high pressure area from human activity. Key features from this Annex related to pelagic habitats are listed in Table 2 .

Table 2: Reference list of species and habitats from Annex 1 of the Integrated Monitoring and Assessment Programme of the Mediterranean Sea and Coast and Related Assessment Criteria (IMAP) (UNEP/MAP, 457 2017).

\begin{tabular}{|c|c|c|c|}
\hline $\begin{array}{l}\text { Predominant } \\
\text { habitat }\end{array}$ & $\begin{array}{l}\text { Specific habitat type or } \\
\text { species to be monitored }\end{array}$ & $\begin{array}{l}\text { Additional } \\
\text { information: specific } \\
\text { representatives } \\
\text { species or habitats }\end{array}$ & $\begin{array}{l}\text { Assessment } \\
\text { monitoring scale }\end{array}$ \\
\hline $\begin{array}{l}\text { Water column - } \\
\text { coastal waters }\end{array}$ & $\begin{array}{l}\text { Coastal waters } \\
\text { phytoplankton } \\
\text { communities }\end{array}$ & HABs & national/regional \\
\hline $\begin{array}{l}\text { Water column - } \\
\text { coastal waters }\end{array}$ & $\begin{array}{l}\text { Coastal waters } \\
\text { zooplankton communities }\end{array}$ & $\begin{array}{l}\text { cf. jellyfish population } \\
\text { dynamics and blooms }\end{array}$ & $\begin{array}{l}\text { national/ } \\
\text { sub-regional }\end{array}$ \\
\hline $\begin{array}{l}\text { Water column - } \\
\text { shelf and oceanic } \\
\text { waters }\end{array}$ & $\begin{array}{l}\text { Shelf and oceanic waters } \\
\text { phytoplankton } \\
\text { communities }\end{array}$ & HABs & Sub-regional \\
\hline $\begin{array}{l}\text { Water column - } \\
\text { shelf and oceanic } \\
\text { waters }\end{array}$ & $\begin{array}{l}\text { Shelf and oceanic waters } \\
\text { zooplankton communities }\end{array}$ & $\begin{array}{l}\text { cf. jellyfish population } \\
\text { dynamics and blooms }\end{array}$ & Sub-regional \\
\hline
\end{tabular}

For the water column - coastal waters habitat high priority has been determined, meaning that sufficient resources at national and/or joint at (sub-) regional scale should be dedicated to acquire relevant data at sufficient spatial and temporal resolution. For the water column - shelf and oceanic waters habitat the priority still needs to be defined. For all the water column habitats the only established indicator is related to chlorophyll $a$ concentration, although there are several monitoring techniques developed both for phytoplankton and zooplankton, and moreover, these functional groups are included in a number of observatory stations and long term monitoring programmes across the Mediterranean Sea.

467 Besides in the Biodiversity Ecological Objective, phytoplankton biomass is largely considered under the EO5 Eutrophication with the Common Indicator 14: Chlorophyll $a$ concentration in water column (UNEP/MAP, 2017). It is recommended that the Contracting Parties rely on the classification scheme on chlorophyll $a$ concentration developed by the Med-GIG under the umbrella of WFD, taking into account the water typology mentioned above. 


\subsection{Suitability of prokaryotes and related variables for the definition of GES}

474 Prokaryotes are dominant organisms in terms of biomass and diversity in marine ecosystems (Salazar et al., 2016; Sunagawa et al., 2015; Whitman et al., 1998). A large fraction of primary production in the ocean becomes dissolved organic matter by various mechanisms in the food web, and this part of primary production is almost exclusively accessible to heterothophic bacteria (Duarte et al., 2013, Jiao and Azam 2011; Robinson and Williams 2005; Williams et al., 2013), which together with cyanobacteria (e.g. Prochlorococcus, Synechococcus) represent the major components of marine picoplankton community. Consequently, marine microorganisms are essential for the functioning of all marine food webs, playing a pivotal role in biogeochemical cycles, carbon sequestration and abatement of pollutants in marine ecosystems (Azam and Malfatti, 2007; Carlson et al., 2007; Gasol et al., 2008; Jiao and Azam, 2011; Zoppini et al., 1995).

As microbial-organic and inorganic matter pool interactions play a key role in ecosystem functioning, changes in the activity, abundance and structure/composition of autotrophic and heterotrophic prokaryotic communities are expected to have significant implications not only in processes like primary production, organic matter re-mineralization and element cycling, but also in energy and carbon fluxes (Azam and Malfatti, 2007; Benner and Herndl, 2011; Jiao and Azam, 2011). Therefore, the suitability of prokaryotes as indicators of environmental quality are widely recognized (Caruso et al. 2004; Cochrane et al., 2010; McQuatters-Gollop et al. 2010; Pomeroy et al., 2007).

Microbial populations are considered potential sentinels of environmental changes since their community composition/structure and function is known to vary in response to environmental changes, and their high sensitivity to contaminants is recognized (Caruso et al., 2016a, b, and references there in). Prokaryotic variables can be crucial for several MSFD descriptors, in particular D1 (Biodiversity), D4 (Food webs), D5 (Eutrophication), D8 (Contaminants) and D9 (Contaminants in seafood). A preliminary screening of prokaryotic parameters that could be potentially used as indicators of environmental quality was already performed by McQuattersGollop et al. in 2010 and revised by Caruso and her colleagues in 2016a. For example, within the set of proposed parameters prokaryotic abundance, biomass and production were listed as potential indicators within MSFD Descriptor D4 (Food Webs). The whole list of potential prokaryotic parameters/variables that could be applied as indicators in different MSFD Descriptors is available in review by Caruso et al. (2016a).

However, despite the importance and effort for the assessment of environmental status, the MSFD takes into consideration only phytoplankton, zooplankton and large metazoa (i.e. benthic macrofauna and fish) and still ignores autotrophic and heterotrophic prokaryotes, which actually represent the majority of the microbial community. As pointed out by Caruso et al. (2016a), prokaryotic parameters should be viewed as complementary indicators for natural and anthropogenic impacts, in particular to investigate the function of microbial communities in different ecological zones and to explore its relationship with different pressures (i.e. temperature increase/decrease, physical disturbance and organic loading) in marine ecosystem.

There is nevertheless still an opportunity to include also prokaryotic components, since in the phase of MSFD initial assessment the prokaryotic community is taken into account, though only for its pathogenic component. Several marine monitoring programs are limited to the identification of few microbial pathogens, mostly cultivable (e.g. enumeration of indicator fecal bacteria, i.e. Escherichia coli, intestinal enterococci and fecal coliform bacteria), using classical culture-based approach in bathing waters and in bivalve molluscs from shellfish waters and harvesting areas. However, several studies have shown that these are not sufficient indicators of fecal pollution to protect human health (Bradshaw et al., 2016; Liang et al., 2015). Several other pathogens, such as bacteria from Vibrionaceae family, Salmonella spp. as well as human enteric 
viruses (e.g. norovirus, rotavirus, hepatitis A virus) are increasing threats for human health (Caruso et al., 2016b and references there in; Gonçalves et al., 2018). Furthermore, one should be aware that since currently widely used identification is mostly based on culture-independent approach, a large fraction of uncultured microorganisms, actually representing between 90 and $99 \%$ of total microbial community, could be missed, among which also known human and animal pathogens. Moreover in D9 the term "contaminants" refers to hazardous substances, such as chemical elements and compounds, with no reference to microbiological contaminants. Another gap deals with the description of the impact of microbial pathogens on the marine environment (e.g. mortality of biota, shifts in community structure due to contamination, transmission of disease etc).

\section{Approaches and legislation framework for GES definition in the Mediterranean}

In the following paragraphs, some interesting findings are presented from the comparison of

534 approaches and legislation framework among the Mediterranean MSs for the definition of GES in 535 the pelagic environment.

\subsection{Comparison of approaches currently implemented for the definition of GES in pelagic habitats of the Mediterranean}

The revision of the GES definitions showed that at the D1 descriptor level all 8 Mediterranean MSs have defined GES. However, not all MSs defined GES and/or environmental targets also in relation to pelagic habitat and plankton communities. The comparison of approaches in defining GES and environmental targets in relation to pelagic habitat in Mediterranean MSs is presented in Table 3. The level of coherence among Mediterranean MSs in the definition of GES related to pelagic habitat is assessed as low.

544 France, Spain and Cyprus defined GES for D1 at the level of Criterion 1.6 (sensu Commission Decision, 2010/477/EU) just for benthic habitats. Several countries set GES in a qualitative way at the Criterion 1.6 level for pelagic habitats and plankton communities, i.e. Greece, Italy, Croatia and Malta. No baselines or thresholds were provided by these countries, except for Greece that provided thresholds for chlorophyll $a$ concentration in coastal waters. Malta set a particular environmental target regarding pelagic habitats, i.e. the acquisition of new knowledge through monitoring programmes. Slovenia is the only MS that provided some quantitative baselines and thresholds for plankton communities, although the GES definition is very general at the criteria level. Slovenia is also the only country that referred also to zooplankton in a quantitative way. 


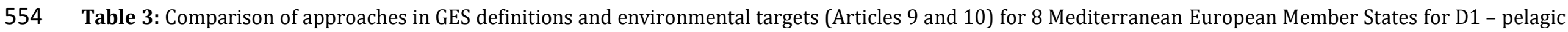
555 habitats. The criteria and indicators refer to Commission Decision 2010/477/EU, followed by Commission Decision 2017/848/EU.

\begin{tabular}{|c|c|c|c|c|}
\hline Country & GES definition (art. 9) & $\begin{array}{l}\text { Environmental targets (art. } \\
10 \text { ) }\end{array}$ & $\begin{array}{l}\text { Associated indicators } \\
\text { (art.10) }\end{array}$ & $\begin{array}{l}\text { Assessment method/Threshold/Reference } \\
\text { conditions }\end{array}$ \\
\hline Slovenia & $\begin{array}{l}\text { Conceptual GES definition is } \\
\text { provided at the general level for } \\
\text { criteria 1.4, } 1.5 \text { and 1.6: The } \\
\text { extent and distribution of } \\
\text { habitats are under natural } \\
\text { conditions. Habitats provide } \\
\text { living space for all functional } \\
\text { groups in accordance with the } \\
\text { natural conditions. The diversity } \\
\text { within functional groups is } \\
\text { maintained. Rare and threatened } \\
\text { habitats are properly protected } \\
\text { and preserved. }\end{array}$ & $\begin{array}{l}\text { No environmental targets } \\
\text { were reported for the } \\
\text { pelagic habitat. }\end{array}$ & $\begin{array}{l}\text { No associated indicators } \\
\text { were reported for the } \\
\text { pelagic habitat. }\end{array}$ & $\begin{array}{l}\text { Quantitative baselines and thresholds for } \\
\text { pelagic habitat are defined for: } \\
\text { - the annual geometric mean of } \\
\text { concentrations of chlorophyll } a \text { in the } \\
\text { surface water layer. } \\
\text { - the shift in the composition of } \\
\text { phytoplankton species or groups } \\
\text { calculated by the index of high } \\
\text { abundances (IE). } \\
\text { - by the multiannual geometric mean of } \\
\text { dry weights of zooplankton. } \\
\text { Additionally, a qualitative baseline is defined } \\
\text { for the frequency of jellyfish occurrence. }\end{array}$ \\
\hline Greece & $\begin{array}{l}\text { Conceptual GES definition is } \\
\text { provided for plankton } \\
\text { communities: } \\
\text { The effects of human activities on } \\
\text { the structure of plankton } \\
\text { communities are reduced to } \\
\text { minimal levels. }\end{array}$ & $\begin{array}{l}\text { Conceptual environmental } \\
\text { target is provided: } \\
\text { Preservation of the } \\
\text { structure of plankton } \\
\text { communities. }\end{array}$ & $\begin{array}{l}\text { - Indicators 1.1.1, 1.2.1: } \\
\text { Species composition and } \\
\text { abundance of plankton } \\
\text { communities. } \\
\text { - Indicator 1.6.2: For the } \\
\text { water column habitat, } \\
\text { phytoplankton biomass } \\
\text { as chlorophyll a } \\
\text { concentration is } \\
\text { considered. }\end{array}$ & $\begin{array}{l}\text { Thresholds or reference conditions for D1 } \\
\text { are not defined for plankton communities } \\
\text { (phytoplankton, zooplankton or } \\
\text { prokaryotes). } \\
\text { For coastal waters, quantitative thresholds } \\
\text { are defined for phytoplankton biomass: } \\
\text { GES threshold is } 0.53 \mu \mathrm{g} / \mathrm{L} \text { and reference } \\
\text { conditions threshold is } 0.20 \mu \mathrm{g} / \mathrm{L} \text { of } \\
\text { chlorophyll a concentration. } \\
\text { Thresholds refer to the 90th percentile of } \\
\text { chlorophyll a values. } \\
\text { There is a } 0.03 \text { correction coefficient for } \\
\text { Greek waters. }\end{array}$ \\
\hline Italy & $\begin{array}{l}\text { Conceptual GES definition is } \\
\text { provided for plankton } \\
\text { communities at the Indicator } \\
\text { 1.6.2. level: }\end{array}$ & $\begin{array}{l}\text { No environmental targets } \\
\text { were reported for the } \\
\text { pelagic habitat. }\end{array}$ & $\begin{array}{l}\text { Indicator } 1.6 .2 \text { Relative } \\
\text { abundance and/or biomass, } \\
\text { as appropriate - considered } \\
\text { elements : }\end{array}$ & $\begin{array}{l}\text { Development in progress: } \\
\text { The indicator 1.6.2. will be developed by } \\
\text { means of elaborations of the data provided } \\
\text { by routine monitoring activities at a nationa }\end{array}$ \\
\hline
\end{tabular}




\begin{tabular}{|c|c|c|c|c|}
\hline & $\begin{array}{l}\text { GES is considered maintained or } \\
\text { achieved when the relative } \\
\text { abundance of the plankton } \\
\text { communities is compatible with } \\
\text { the natural conditions, or it } \\
\text { presents a slight deviation from } \\
\text { these conditions. }\end{array}$ & & $\begin{array}{l}\text { pelagic habitat } \\
\text { (expected to be developed } \\
\text { by the year 2018). }\end{array}$ & $\begin{array}{l}\text { level and from specific monitoring } \\
\text { programmes already planned or to be } \\
\text { defined. Metrics: direct measures of relative } \\
\text { abundances for phytoplankton and } \\
\text { zooplankton. } \\
\text { Phytoplankton: Specific composition and } \\
\text { abundance (Diversity Indices), succession, } \\
\text { frequencies of algal blooms. } \\
\text { Zooplankton: Specific composition and } \\
\text { abundance (Diversity Indices), changes in } \\
\text { the ratios between functional groups (e.g. } \\
\text { large size/small size copepods, } \\
\text { meroplankton/holoplankton, } \\
\text { herbivores/non-herbivores), indicator } \\
\text { species. }\end{array}$ \\
\hline Croatia & $\begin{array}{l}\text { Conceptual GES definition is } \\
\text { provided for plankton } \\
\text { communities at the criterion } 1.6 \\
\text { level : } \\
\text { Taxonomic biodiversity and } \\
\text { abundance of plankton species is } \\
\text { preserved in accordance with the } \\
\text { prevailing biotic and abiotic } \\
\text { conditions which are not } \\
\text { significantly negatively impacted } \\
\text { by human activities. }\end{array}$ & $\begin{array}{l}\text { Conceptual environmental } \\
\text { target is provided: } \\
\text { Relative abundances and } \\
\text { plankton biomass are not } \\
\text { significantly changed from } \\
\text { naturally occurring } \\
\text { conditions. }\end{array}$ & $\begin{array}{l}\text { - Indicators 1.1.1,1.2.1: } \\
\text { Species composition and } \\
\text { abundance of plankton } \\
\text { communities. } \\
\text { - Indicator 1.6.2: For the } \\
\text { water column habitat, } \\
\text { phytoplankton biomass } \\
\text { as chlorophyll } a \\
\text { concentration is } \\
\text { considered. }\end{array}$ & $\begin{array}{l}\text { Development in progress: } \\
\text { Some indications of the statistical methods } \\
\text { (NMDS, PCA) and ecological indices (Bray- } \\
\text { Curtis similarity coefficient, diversity } \\
\text { indices, Shannon-Wiener and Pielou, } \\
\text { number of species) to be used are provided. }\end{array}$ \\
\hline France & $\begin{array}{l}\text { GES definition for pelagic habitat } \\
\text { or plankton communities was not } \\
\text { provided. }\end{array}$ & $\begin{array}{l}\text { No environmental targets } \\
\text { were reported for the } \\
\text { pelagic habitat. }\end{array}$ & $\begin{array}{l}\text { No associated indicators } \\
\text { were reported for the } \\
\text { pelagic habitat. }\end{array}$ & - \\
\hline Spain & $\begin{array}{l}\text { GES definition for pelagic habitat } \\
\text { or plankton communities was not } \\
\text { provided. }\end{array}$ & $\begin{array}{l}\text { No environmental targets } \\
\text { were reported for the } \\
\text { pelagic habitat. }\end{array}$ & $\begin{array}{l}\text { No associated indicators } \\
\text { were reported for the } \\
\text { pelagic habitat. }\end{array}$ & - \\
\hline Cyprus & $\begin{array}{l}\text { Conceptual GES definition is } \\
\text { provided at the general level of } \\
\text { D1: }\end{array}$ & $\begin{array}{l}\text { Reported environmental } \\
\text { targets are the same as GES } \\
\text { definition. }\end{array}$ & $\begin{array}{l}\text { No associated indicators } \\
\text { were reported for the } \\
\text { pelagic habitat. }\end{array}$ & $\begin{array}{l}\text { For D1, the assessment method is based on } \\
19 \text { indicators, but none of them is related to } \\
\text { plankton. }\end{array}$ \\
\hline
\end{tabular}




\begin{tabular}{|l|l|l|l|l|}
\hline & $\begin{array}{l}\text { The marine environment of } \\
\text { Cyprus is considered to be in } \\
\text { good environmental status by the } \\
\text { year 2020 if biological diversity is } \\
\text { maintained. The quality and } \\
\text { occurrence of habitats and the } \\
\text { distribution and abundance of } \\
\text { species are in line with prevailing } \\
\text { physiographic, geographic and } \\
\text { climatic conditions. }\end{array}$ & & & $\begin{array}{l}\text { For coastal waters, quantitative thresholds } \\
\text { are defined for phytoplankton biomass: } \\
\text { GES threshold is } 0.53 \mu g / L \text { and reference } \\
\text { conditions are below 0.20 } \mu \mathrm{g} / \mathrm{L} \text { of } \\
\text { chlorophyll } a \text { concentration. } \\
\text { Thresholds refer to the 90th percentile of } \\
\text { chlorophyll } a \text { values. }\end{array}$ \\
\hline Malta & $\begin{array}{l}\text { Conceptual GES definition is } \\
\text { provided at the general level of } \\
\text { criterion 1.6: } \\
\text { The structure and function of } \\
\text { marine habitats ensure their } \\
\text { long-term viability. }\end{array}$ & $\begin{array}{l}\text { Conceptual environmental } \\
\text { target is provided: } \\
\text { To strengthen knowledge } \\
\text { via updated data on key } \\
\text { characteristics of the water } \\
\text { column, including plankton } \\
\text { communities, in order to } \\
\text { define this habitat type in } \\
\text { line with the requirements } \\
\text { of the Marine Strategy } \\
\text { Framework Directive. }\end{array}$ & $\begin{array}{l}\text { Level of knowledge on water } \\
\text { column habitat types. }\end{array}$ & $\begin{array}{l}\text { Development in progress: } \\
\text { To be established through the MSFD } \\
\text { monitoring programme by 2018. }\end{array}$ \\
& & & \\
\hline
\end{tabular}




\subsection{Comparison of European Commission Decisions 2017/848/EU and $2010 / 477 / E U$ in the view of pelagic habitats}

559 In 2017 a new Commission Decision 2017/848/EU was put in force as the evolution of the Commission Decision 2010/477/EU, after having reviewed the criteria and methodological standards on GES of marine waters, and the specifications and standardised methods for monitoring and assessment. The scope of the new Commission Decision 2017/848/EU (hereafter 2017/848/EU) is to ensure that the second cycle of implementation in the MSs further contributes to the achievement of the objectives of the MSFD and yields more consistent determinations of GES. For this, the new Commission Decision aims to deliver a clearer, simpler, more concise, more coherent and comparable set of GES criteria and methodological standards.

The Annex of 2017/848/EU sets the criteria and methodological standards for GES in marine waters, which are in Part II related to the descriptors linked to the relevant ecosystem elements, also for pelagic habitats (D1) among others. Table 4 shows the criteria and methodological standards specifically for pelagic habitats, set by

572 2017/848/EU.

Table 4: Criteria, including criteria elements, and methodological standards related to Pelagic habitats (from Annex, Part II of the Commission Decision 2017/848/EU)

\begin{tabular}{|c|c|c|}
\hline Criteria elements & Criteria & Methodological standards \\
\hline $\begin{array}{l}\text { Pelagic broad habitat types } \\
\text { (variable salinity }\left({ }^{1}\right) \text {, coastal, } \\
\text { shelf and oceanic/beyond } \\
\text { shelf), if present in the region } \\
\text { or subregion, and other } \\
\text { habitat types as defined in the } \\
\text { second paragraph. } \\
\text { MSs may select, through } \\
\text { regional or subregional } \\
\text { cooperation, additional } \\
\text { habitat types according to the } \\
\text { criteria laid down under } \\
\text { 'specifications for the } \\
\text { selection of species and } \\
\text { habitats'. }\end{array}$ & $\begin{array}{l}\text { D1C6 - Primary: The } \\
\text { condition of the habitat type, } \\
\text { including its biotic and abiotic } \\
\text { structure and its functions } \\
\text { (e.g. its typical species } \\
\text { composition and their relative } \\
\text { abundance, absence of } \\
\text { particularly sensitive or } \\
\text { fragile species or species } \\
\text { providing a key function, size } \\
\text { structure of species), is not } \\
\text { adversely affected due to } \\
\text { anthropogenic pressures. MSs } \\
\text { shall establish threshold } \\
\text { values for the condition of } \\
\text { each habitat type, ensuring } \\
\text { compatibility with related } \\
\text { values set under Descriptors } \\
2,5 \text { and } 8 \text {, through regional or } \\
\text { sub-regional cooperation. }\end{array}$ & $\begin{array}{l}\text { Scale of assessment: } \\
\text { Subdivision of region or } \\
\text { subregion as used for } \\
\text { assessments of benthic broad } \\
\text { habitat types, reflecting } \\
\text { biogeographic differences in } \\
\text { species composition of the } \\
\text { habitat type. } \\
\text { Use of criteria: } \\
\text { The extent to which good } \\
\text { environmental status has } \\
\text { been achieved shall be } \\
\text { expressed for each area } \\
\text { assessed as: } \\
\text { (a) an estimate of the } \\
\text { proportion and extent of each } \\
\text { habitat type assessed that has } \\
\text { achieved the threshold value } \\
\text { set; } \\
\text { (b) a list of broad habitat } \\
\text { types in the assessment area } \\
\text { that were not assessed. }\end{array}$ \\
\hline
\end{tabular}

In comparison to 2010/477/EU, the new 2017/848/EU is far more precise regarding the pelagic habitat. The Criterion 1.6 "Habitat condition", that in the 2010/477/EU was based on assessment of three Indicators (1.6.1 Condition of the typical species and communities, 1.6.2 Relative abundance and/or biomass, as appropriate, and 1.6.3 
type is considered as a whole for its biotic and abiotic characteristics and its functions. These habitat types are defined under the Criteria elements: broad pelagic habitat types that the MSs should take into consideration in their assessment are mandatory, and moreover, it allows for more habitat types if their need is established through (sub-) regional cooperation. In the "Specifications and standardised methods for monitoring and assessment relating to theme Pelagic habitats", the section Coastal habitat type is specified more precisely and a connection is made to Criteria from D2, D5, D7 and D8, that define pressures to the pelagic habitats. Methodological standards refer to the scale of assessment and units of measurements for the Criterion.

\section{Gap analysis and priority needs to improve coherence}

594

595

596

597

598

599

600

601

602

603

604

605

606

607

608

609

610

611

612

613

614

615

616

617

618

619

620

621
With the scope to form a basis for gap and quality analysis, for refining existing indicators and developing new, Cozzoli and Basset (2016) created an open electronic catalogue in the frame of the ActionMed EU project. This database listed published biodiversity indicators/indices/metrics, adopted also in the Mediterranean, with their information sources (related scientific publications and technical reports). In this sense, it can serve as an inventory of existing methods to assess marine environmental status in the Mediterranean Sea. A list of 91 entries in total related to phytoplankton and plankton in general can be found in this open electronic catalogue "ActionMed 1.1.2: Indicators catalogue", developed under the umbrella of ActionMed project, and accessible at http://193.204.79.93:3838/SHINY/SHINY_SERVER/ACTIONMEDCATALOGUE/.

Each record in this catalogue is a unique combination of the considered indicator/index/metric and of the number of documents in which it was published. The database includes both scientific publications and technical reports, and the number of entries in there is a proxy for the scientific knowledge and the research interest and effort devoted on that topic. Indicators for D10 (Litter) and D11 (Energy \& Noise) are poorly or not represented in the catalogue. The monitoring of these descriptors is a relatively novel aspect of the MFSD that was generally not considered in previous monitoring plans, and therefore few relevant indicators have been fully developed and published at the time of the analysis.

According to this electronic catalogue, the majority of reported indicators focuses on biological elements mainly (for D1, D4, D6 of MSFD), while indicators accounting for hydrographic features (for D7) are less reported (Fig. 2a). The MSFD elements of Macrozoobenthos, Fish and Habitat appeared to be most covered in the literature (Fig. $2 b)$. Surprisingly, phytoplankton is relatively scarcely covered, despite its importance in monitoring programmes and its strong link with D5. Zooplankton is less represented, with biomass and distributional range as most popular indicators. 


\section{Descriptors}

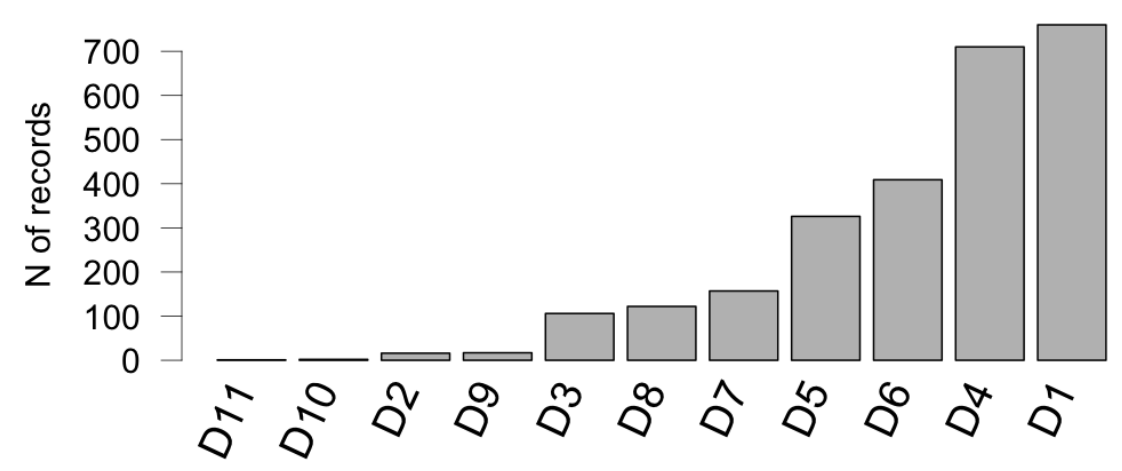

\section{Elements}

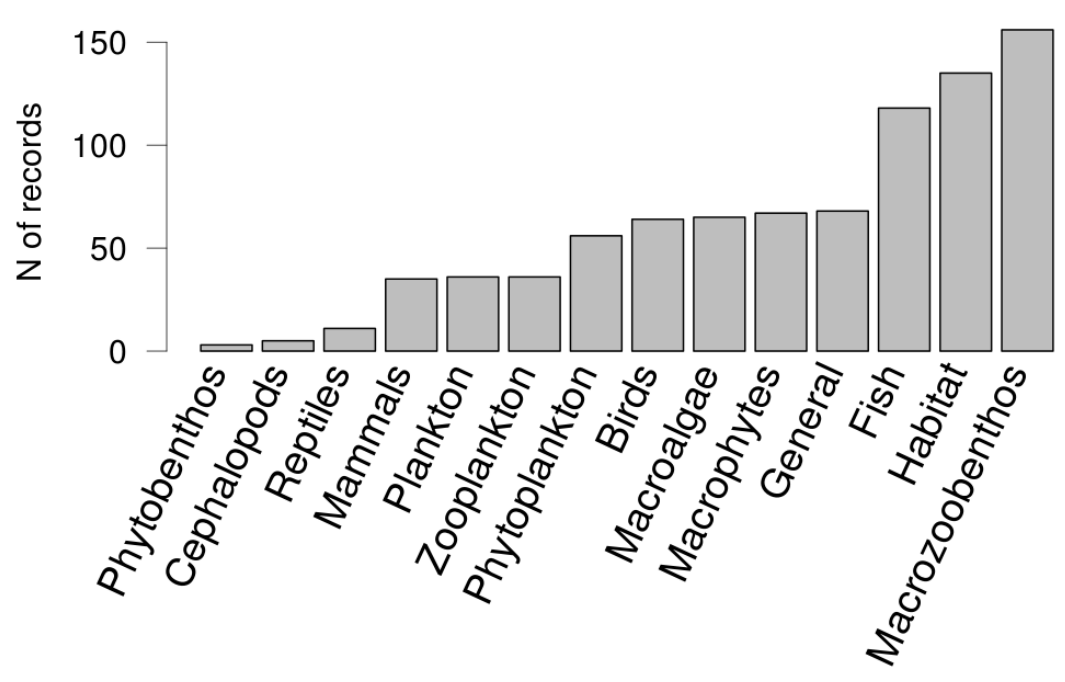

Fig. 2. Count of records in the literature which refer to a specific MSFD descriptor (a) and MSFD biodiversity element (b), as reported in the electronic catalogue of Cozzoli and Basset (2016).

Among Plankton indicators, the "Biomass ratio of functional groups" and the "Abundance ratio of functional groups" appeared to be most represented in the literature (Fig. 3a). The most popular Phytoplankton indicators are "Species diversity (Menhinick) of phytoplankton" and "Chlorophyll $a$ concentration" (Fig. 3b). Despite the high sensitivity of phytoplankton to environmental impacts and especially to nutrients loads, a relatively restricted number of studies have been published about this element (56 records). The majority of published works report only total chlorophyll $a$ measurements ( 4 records). This could be attributed to the fact that chlorophyll $a$ : i) is the most commonly used parameter as a proxy for phytoplankton biomass, ii) requires 
easy and not expensive analyses, and iii) there were substantial efforts for the intercalibration of the assessment methodology based on chlorophyll $a$ throughout the Mediterranean in the frame of WFD and MSFD, coordinated by JRC EC and by UNEP/MAP. The most popular Zooplankton indicators are "Biomass of Zooplankton" and "Distributional range of Zooplankton" (Fig. 3c). Many of these operational indicators have not been paired with thresholds in order to assess GES and accomplish legally imposed targets in the frame of the MSFD implementation. Furthermore, most of the indicators lack any measure of confidence or uncertainty associated with their assessment results (Cozzoli et al., 2017). Indicators for prokaryotes to be used within the context of the MSFD assessment were not found in the literature.

649

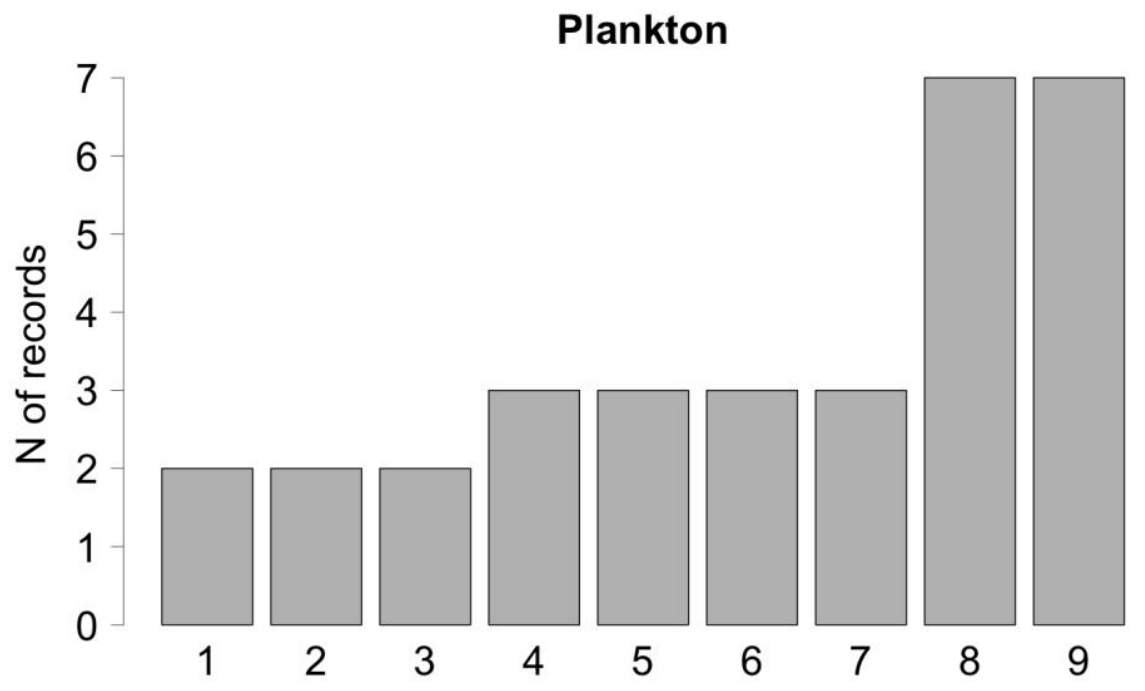

1) Evenness (Sheldon) of phytoplankton

2) Species diversity (Margalef index) of plankton

3) Species dominance (Breger-Parker) of plankton

4) Abundance of phyto- and zooplankton

5) Biomass of phyto- and zooplankton

6) Species diversity (Shannon index) of plankton

7) Species richness of plankton

8) Abundance ratio of functional groups (in terms of life form) of plankton

9) Biomass ratio of functional groups (in terms of life form) of plankton 


\section{Phytoplankton}

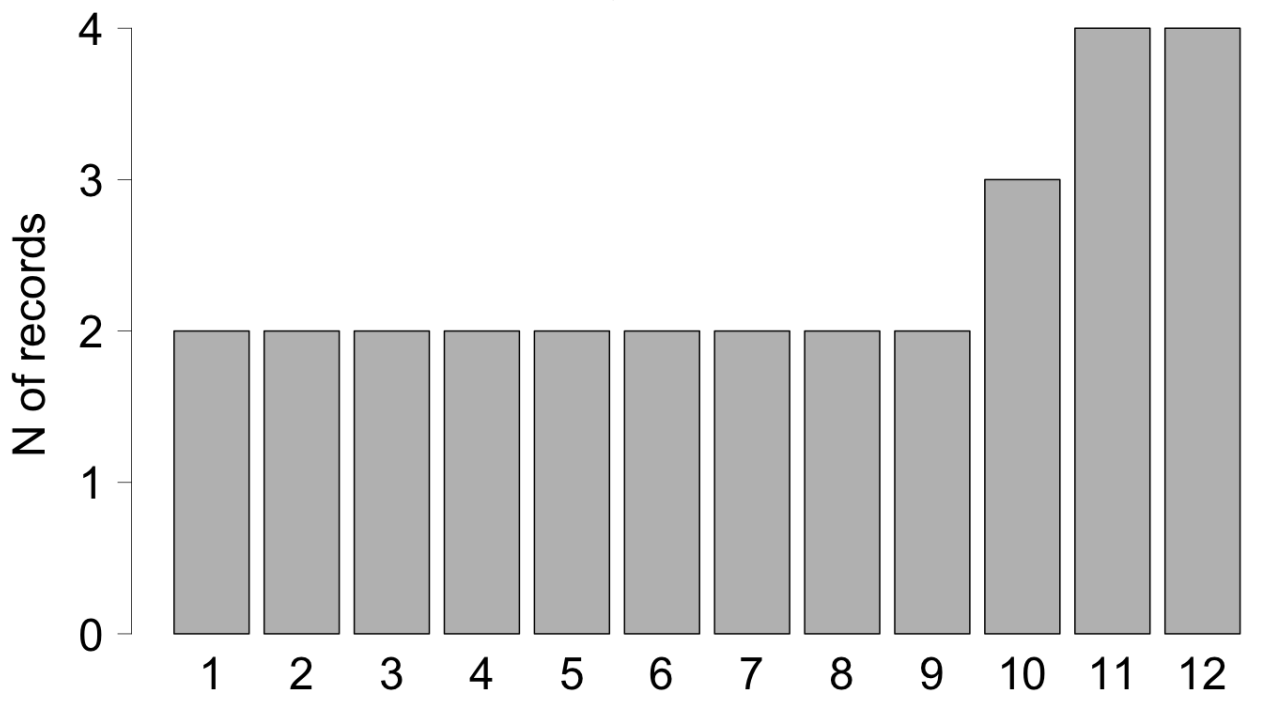

1) Abundance of phytoplankton

2) Abundance ratio of selected dinoflagellates (C-strategy species)

3) Biomass of phytoplankton

4) Distributional range of phytoplankton

5) ISS_phyto index of size spectra sensitivity phytoplankton

6) Production of phytoplankton

7) The Elevated Phytoplankton (Single Taxa) Counts Tool

8) WFD Latvian Assessment method for phytoplankton status based on chlorophyll a concentrations

9) WFD Latvian Assessment method for phytoplankton status based on phytoplankton biomass

10) Abundance of selected phytoplankton species and taxa groups

11) Concentration of $\mathrm{Chl} \mathrm{a}$

12) Species diversity (Menhinick) of phytoplankton 


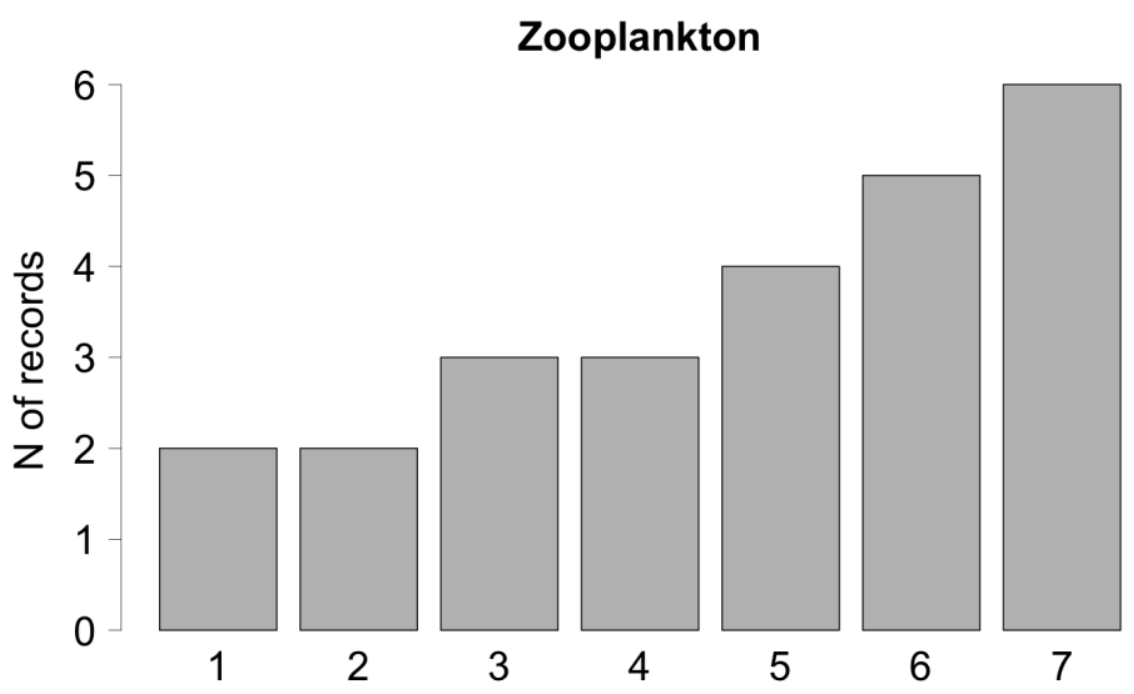

\footnotetext{
1) Abundance of selected zooplankton species and taxa groups

2) Body length distribution of zooplankton

3) Abundance and composition of zooplankton

4) Abundance of zooplankton

5) Biomass of Mnemiopsis leidyi

6) Distributional range of zooplankton

7) Biomass of zooplankton
}

Fig. 3. Count of records in the literature which refer to a specific plankton indicator (a), Phytoplankton indicator (b) and Zooplankton indicator (c). Only the cases with 2 or more records are reported.

\subsection{Specific remarks on gaps related to plankton communities}

The most evident gaps arising from the review of approaches to define and assess environmental status by means of plankton indicators in the pelagic habitat of the Mediterranean are:

- A consistent definition of GES has not been achieved. GES definition remains general and varies a lot among Mediterranean MSs.

- The environmental targets of MSs are too general and differ considerably.

- Quantitative (operational) thresholds and baselines lack for many biodiversity indicators.

- The integration of existing EU legislation and regional sea conventions (Barcelona convention) standards is poor.

- National monitoring areas and sub-areas present a large heterogeneity in abiotic drivers and species distribution. It is therefore difficult and often inappropriate to select common thresholds for impact level. 
- Common and consistent methodological approaches by MSs for biodiversity assessment are scarce.

- Scarcity or fragmentation of data, only short time series for many areas.

\subsection{Priority needs for development of methodologies related to phytoplankton}

679

The water column components phytoplankton and zooplankton are covered by fewer indicators in the Mediterranean than in other regional seas, e.g. Black Sea, Baltic Sea and NE Atlantic Ocean. However, many phytoplankton and zooplankton indicators could be used as "early warning indicators", because of their ability to respond quickly to environmental changes and give feedback about changes happening in the food webs and ecosystems (Teixeira et al., 2014).

In general, there is a great heterogeneity of available data in terms of sampling frequency, study area, methodologies etc., in the Mediterranean. Most of the Mediterranean MSs have data from their national monitoring programmes, whether related to WFD, MSFD and/or Barcelona convention, and they are mainly limited to coastal waters. Available data from open waters are even more scarce, dispersed and heterogeneous. This scarcity or fragmentation of data creates the need for more efforts to find archival data, for example through data rescue projects.

An important aspect is to include areas with different pelagic habitat characteristics in order to be able to differentiate between structural and/or functional differences of plankton communities. D'Ortenzio and Ribera d'Alcalà (2009) propose the division of the Mediterranean Sea in areas according to the analysis of 10 years of satellite derived chlorophyll $a$ data. They assume that areas with similar patterns in the seasonal time series of surface chlorophyll $a$ concentration share also similar mechanisms driving the functioning of the ecosystem. Their analysis ended with seven clusters divided in four groups: coastal, blooming, intermittently blooming and no-bloom. According to their study, for example the Adriatic and the Aegean Sea belong to different clusters, mainly to coastal and no-bloom, respectively.

There is also a gap in the reporting of the frequency and intensity of pressures on biodiversity. For example, there are few indicators that demonstrate the pressureimpact relationship and include phytoplankton but they are not operational, as estimated in the frame of ActionMed project (Stanca et al., 2017). Given the above facts, it is rather impossible to get conclusions for large scale patterns on seasonal or annual basis for the Mediterranean.

Phytoplankton biodiversity indicators are mostly related to abundance, biomass, distribution, diversity and richness, and therefore cover mainly the Criteria 1.1 "Species distribution" and 1.2 "Population size", as mentioned in the repealed Commission Decision 2010/477/EU. So far there are biodiversity indicators at the ecosystem level reported only from the NE Atlantic. It appears that in the Mediterranean there is a considerable gap for Criteria 1.6 "Habitat condition", 1.7 "Ecosystem structure" and 1.8 "Ecosystem processes and functions". Therefore there is a substantial need to include other components which in the new Commission Decision 2017/848/EU are part of the Habitat condition as biotic and abiotic structure of pelagic habitat and its functions (old Criteria 1.6 "Habitat condition") and the Ecosystem related criteria included in the Food webs theme (old Criteria 1.7 "Ecosystem structure" and 1.8 "Ecosystem processes and functions"). 


\subsection{Priority needs for development of methodologies related to zooplankton}

Until recently, the application of the zooplankton indicators for GES was mainly on a regional base and still is under development due to several difficulties. One of the difficulties in establishing indicators is the need to discriminate change due to human pressure from the considerable natural variability (in time and space) in the assemblages of species that are found in coastal and open seas. Furthermore, the great variety of species that make up plankton communities means that a large amount of information needs to be summarized. Due to the sporadic occurrence, and sometimes uncertain taxonomic affinity of all but the most common planktonic organisms, it is difficult to imagine distinguishing environmental change on a species-by-species basis. Good quality long-term zooplankton data that could provide the basis for such assessments are not only scarce, but the existing ones are often discontinued due to the financial constraints connected to the maintenance of monitoring programmes.

Plankton exhibits variability on a range of spatial and temporal scales and the assemblage of species and populations of individual species are not fixed in time and space but are dynamic. Also, a lack of zooplankton data is a key information gap. To assess the environmental status of plankton at the regional sea level, it is important that sampling stations are located in all the eco-hydrodynamic regions within each regional sea.

Detecting alterations in zooplankton and planktonic communities in general due to human pressures or climate change is not a trivial task. Any proper method should be capable of quantifying the natural dynamic variability of plankton populations and take into account the seasonal succession of some species. Furthermore, the status of zooplankton is of concern in relation to biodiversity (D1), food-web (D4) and eutrophication (D5) descriptors of the MSFD. Therefore, zooplankton indicators are required for each of these descriptors, and potentially combined with other plankton indicators, they could provide a holistic view of change in the status of the plankton community in all its aspects. This approach was tested and reported recently by Aubert et al. $(2017 ; 2018)$ in the frame of the EcApRHA project for the OSPAR region in NE Atlantic Ocean.

\subsection{Priority needs for development of methodologies related to prokaryotes}

A main limitation of the MSFD is that most indicators are descriptive and they focus on species distributions / biodiversity, giving only partial information on the structure of the ecosystem with possible limitations in environmental quality assessment (Borja et al., 2008). The description of diversity and knowledge on the role of prokaryotes in ecological processes in the marine environment is poor if not completely neglected in MSFD. Knowledge improvements, methodology standardization and a holistic approach to the study of marine ecosystems are urgently needed in order to improve our understanding of the role of prokaryotes in ecosystem structure and functioning (Cochrane et al., 2010; Glockner et al., 2012). The diversity of prokaryotes in marine ecosystems is high (Pedrós-Alió, 2006; Sunagawa et al., 2015) so this component could/should be included within D1. Furthermore, new culture-independent, molecularbased approaches and novel omic techniques should be applied in monitoring programmes and can/should be used to study marine microbial populations and their variability through time and space in relation to environmental parameters. In the long term, the application of these novel approaches and techniques would bring more accurate, reliable, time-saving and even less expensive methods to describe the diversity 
of total microbial community/population of interest and/or of their pathogenic constituents.

With the application of enumeration techniques for prokaryotes in marine samples (such as flow cytometry and epifluorescence microscopy), prokaryotic abundance and biomass have been included in some routine monitoring programmes. As suggested by Caruso et al. (2016a), these two parameters could be applied as indicators within MSFD descriptor D4 (Food Webs) and D5 (Eutrophication). In order to evaluate the present and future abundance, biomass and distribution of prokaryotes, we need to establish standardized procedures for monitoring of these microorganisms at a large scale, high frequency and for long periods (Caroppo, 2015).

There are several different ways in which prokaryotes data can be used to estimate ecosystem properties or environmental status. The most essential is the abundance of specific microbial assemblages: pico-phytoplankton and heterotrophic prokaryotes. The ratio between the various microbial assemblages: picocyanobacteria/eukaryotic picophytoplankton can be used to indicate nutrient levels, as cyanobacteria are more likely to be abundant in low nutrient oligotrophic environments, while eukaryotes tend to dominate in high nutrient conditions (Calvo-Díaz et al., 2008). High abundance of the cyanobacterium Prochlorococcus or dominance of pico-eukaryotes is associated with nutrient-rich environments (Stomp et al., 2007). Since scattered light is proportional to cell size and fluorescence is proportional to pigment content, it is possible to differentiate among various groups of microorganisms according to their average cell size, types of pigments and pigment ratios (La Ferla et al., 2014; Morán et al., 2015).

On the other hand, heterotrophic bacteria are the major consumers of phytoplankton production and because of their large surface area-to-volume ratio these small but abundant organisms have the greatest ability to interact with chemical substances in seawater, of both natural and anthropogenic origin. Therefore, the greatest reservoir of carbon in the biosphere (Hansel et al., 2009) - the dissolved organic matter pool - is almost exclusively accessible to heterotrophic bacterioplankton. The uptake of organic matter by bacteria is a major carbon-flow pathway and its variability can change the overall patterns of carbon flux in the ocean (Azam 1998; Azam and Malfatti, 2007). The microbial loop channels energy and nutrients via bacteria to protozoa, to larger zooplankton and on to fish (Azam 1998; Azam and Long, 2001; Azam and Malfatti, 2007; Pomeroy et al., 2007). Moreover, the recently proposed concept of a microbial carbon pump (MCP) suggests that microbial metabolism of labile DOM, which is rapidly respired back to $\mathrm{CO} 2$ or assimilated by diverse microbes, and trophic interactions within the microbial loop generate refractory DOM (RDOM), a persistent form of DOM that can survive for thousands of years, constituting a previously undescribed mechanism of carbon sequestration (Jiao et al., 2010). The MCP provides a conceptual framework that describes how microbes are also DOM producers and contributors to the creation of RDOM. The central questions of the MCP concern the structure-specific molecular consequences of microbe and organic matter interactions (Jiao and Azam, 2011). Therefore, not only the abundance, biomass and productivity of hetetrotrophic prokaryotes should be considered, but also their community structure and function should/could be included as indicator within several MSFD Descriptors (for example D1, D4 and D5, but even D8 and D9) to assess environmental status and set up effective mitigation measures and to address the relationship between diversity and ecosystem functioning. 
In order to improve coherence of approaches for pelagic habitats at regional and/or sub-regional scale, some general recommendations are presented:

- Establish threshold values and determine baselines to enable consistency.

- Determine common methodologies to empower comparability and consistency.

- Target on priority species and habitats.

- Regular and specific monitoring programmes, impact assessment studies and research programs should be undertaken at different levels (from MS to regional level). Consider also a regional approach in monitoring planning.

- There is a persistent need to increase funding for methodological research in national monitoring programmes.

- Integrate EU legislation and Regional Agreements and Conventions.

- Take initiatives at policy / legislation level to achieve or maintain GES.

Besides these general recommendations for plankton indicators, there are some more specific ones oriented towards the easier development of assessment methodologies and their putting in practice:

- Compilation of written guidelines for calculating and interpreting indicator values.

- Coordination of statistical evaluation of the scoring system among indicators.

- Completion of a map showing the eco-hydrodynamic regions, and development of networks of sampling stations (also based on existing sampling locations) to ensure that they are representative of the eco-hydrodynamic regions within an assessment area, including sampling of plankton parameters (phytoplankton, zooplankton and prokaryotes) in coastal and open waters.

- Substantial work is still needed to clearly define the use of planktonic communities as indicators for the assessment of GES, due to the lack of crucial data with adequate spatial and temporal coverage and the lack of established methods at the regional/subregional level.

- Implementation of simplified methods for phytoplankton size spectra assessment and related assessment metrics.

- Improved assessment of zooplankton biomass and standardization of biomass calculations are needed.

- Implementation of routine sampling for zooplankton size fractions using nets with appropriate mesh sizes (e.g. $50 \mu \mathrm{m}$ and $200 \mu \mathrm{m}$ ), and bottle samples for microzooplankton $(<50 \mu \mathrm{m})$.

- There is a need to begin widespread sampling of prokaryotes to address geographical gaps in the coverage of Mediterranean, about the role of prokaryotes in the biogeochemical cycles.

- Studies about the interactions between microbes and other planktonic organisms and higher trophic levels, and between microbes and organic/inorganic matter pool. 
859 For the assessment of GES at the Mediterranean region scale, in Table 5 we suggest the 860 use of metrics and indicators that would facilitate the comparability of biodiversity

861 components of the water column habitat.

862 To summarize in conclusion, scientists need to agree on and follow common 863 methodological approaches for biodiversity assessment in order to increase 864 compatibility and consistency; test existing biodiversity indices with good performance 865 in case studies among MSs; define GES thresholds and baselines for pelagic biodiversity 866 indicators at the national and regional level, where feasible; suggest measures towards 867 GES achievement in the pelagic environment. 
Table 5: Suggested methodologies towards GES determination for different biodiversity components of the water column habitat in the

\begin{tabular}{|c|c|c|c|c|}
\hline $\begin{array}{l}\text { Biodiversity } \\
\text { component }\end{array}$ & Methodology & Reason & Necessary steps for the development of GES targets and standards & Reference \\
\hline \multirow{3}{*}{ 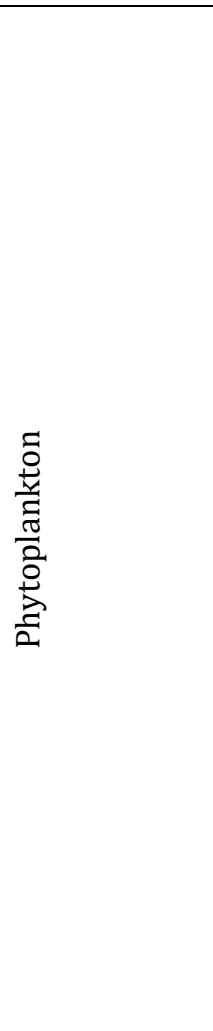 } & Chlorophyll a & $\begin{array}{l}\text { Availability of data, } \\
\text { easy to measure, } \\
\text { reliable data, remote } \\
\text { sensing }\end{array}$ & $\begin{array}{l}\text { This is a well intercalibrated paramenter with specified GES targets among MSs } \\
\text { but not among non-european Mediterranean countries }\end{array}$ & $\begin{array}{l}\text { Commission } \\
\text { Decision, } \\
\text { 2018/229/EU }\end{array}$ \\
\hline & $\begin{array}{l}\text { Size-related } \\
\text { metrics, e.g. ISS- } \\
\text { phyto }\end{array}$ & $\begin{array}{l}\text { High precision, low } \\
\text { uncertainty, no need } \\
\text { for taxonomic } \\
\text { expertise }\end{array}$ & $\begin{array}{l}\text { Biovolume and biomass intercalibration in order to have same comparable } \\
\text { measurement units, linear dimensions and formulas, e.g. through the Phyto } \\
\text { Traits Thesaurus (Rosati et al., 2017) for standardized geometry and } \\
\text { morphology terms, and the Atlas of shape } \\
\text { (http://phytobioimaging.unisalento.it/en- } \\
\text { us/products/AtlasOfShapes.aspx?ID_Tipo=0) for standardized geometric } \\
\text { biovolume and surface areas' formulas }\end{array}$ & $\begin{array}{l}\text { Cozzoli et al., } \\
\text { 2017; Vadrucci } \\
\text { et al., } 2013\end{array}$ \\
\hline & $\begin{array}{l}\text { Diversity and } \\
\text { dominance } \\
\text { metrics, e.g. } \\
\text { Shannon-Wiener's } \\
\text { diversity index and } \\
\text { Berger-Parker's } \\
\text { dominance index }\end{array}$ & $\begin{array}{l}\text { High accuracy, focus } \\
\text { on the most } \\
\text { abundant taxa }\end{array}$ & $\begin{array}{l}\text { Taxonomic intercalibration through basic/advanced courses and meetings in } \\
\text { order to adopt a common line for taxonomy harmonization, especially when } \\
\text { using and comparing phytoplankton species composition, abundance and } \\
\text { biomass as indicators of environmental impacts }\end{array}$ & $\begin{array}{l}\text { Cozzoli et al., } \\
\text { 2017; Facca and } \\
\text { Sfriso, } 2009\end{array}$ \\
\hline
\end{tabular}




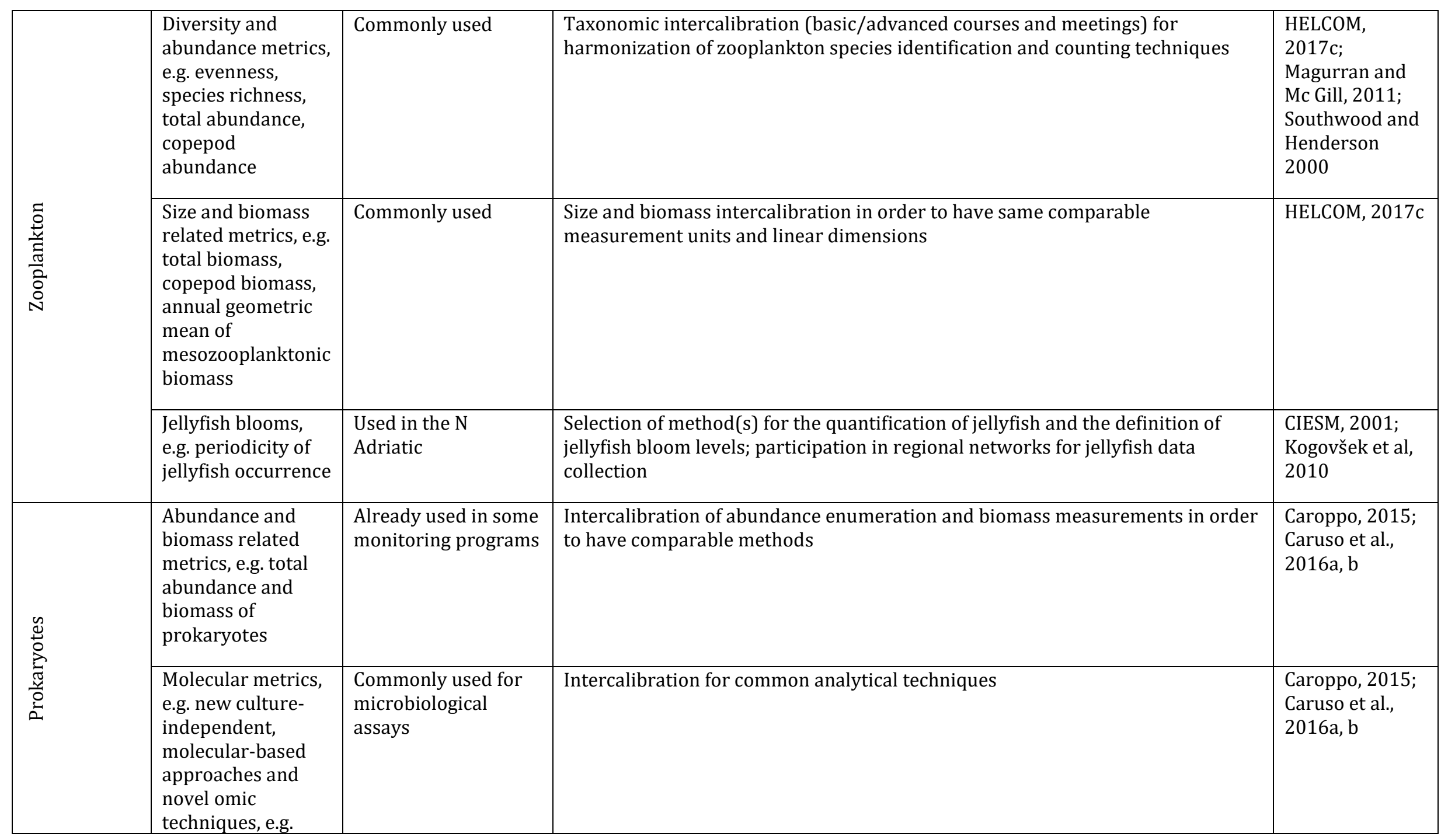


DNA barcoding

Next Generation

Sequencing, RT-

qPCR 


\section{Acknowledgements}

We are grateful to the two anonymous reviewers for their constructive comments on the manuscript. This study was supported by the project MEDCIS: Support Mediterranean MSs towards Coherent and coordinated Implementation of the second phase of the MSFD, funded by the European Commission, DG Environment, Grant agreement 11.0661/2016/748067/SUB/ENV.C2 , Coordinator Dr. K. Pagou.

\section{References}

Alexandrov, B. G., Terenko, L. M., Nesterova, D. A., 2012. The First Case of a Bloom of Nodularia spumigena Mert. ex Born. et Flah. (Cyanophyta) in the Black Sea. IJA. 14, 31-43. https://doi.org/10.1615/InterJAlgae.v14.i1.30 http://www.dl.begellhouse.com/journals/7dd4467e7de5b7ef,4fc8aedf026987a5,2 62cb6d449846822.html

Azam, F., 1998. Microbial control of oceanic carbon flux: the plot thickens. Science. 280, 694-696. https://doi.org/10.1126/science.280.5364.694

http://science.sciencemag.org/content/280/5364/694

Azam, F., Long, R. A., 2001. Oceanography: sea snow microcosms. Nature. 414, 495-498. https://doi.org/10.1038/35107174 https://www.nature.com/articles/35107174

Azam, F., Malfatti, F., 2007. Microbial structuring of marine ecosystems. Nature Rev. Microbiol. 5, 782-91. https://doi.org/10.1038/nrmicro1747 https://www.nature.com/articles/nrmicro1747

Aubert, A., Rombouts, I., Artigas, F., Budria, A., Ostle, C., et al., 2017. Combining methods and data for a more holistic assessment of the plankton community. Deliverable WP1.2. EcApRHA, OSPAR and EU project. ISBN: 978-1-911458-22-7.

Aubert, A., Antajan, E., Lynam, C., Pitois, S., Pliru, A., Vaz, S., Thibault, D., 2018. No more reason for ignoring gelatinous zooplankton in ecosystem assessment and marine management: Concrete cost-effective methodology during routine fishery trawl surveys. Mar. Policy. 89, 100-108. https://doi.org/10.1016/j.marpol.2017.12.010 https://www.sciencedirect.com/science/article/pii/S0308597X17305018

Bacha, M., Amara, R., 2009. Spatial, temporal and ontogenetic variation in diet of anchovy (Engraulis encrasicolus) on the Algerian coast (SW Mediterranean). Estuar., Coast. and Shelf Science. 85, 257-264. https://doi.org/10.1016/j.ecss.2009.08.009 https://www.sciencedirect.com/science/article/pii/S027277140900393X

Bargu, S., Koray, T., Lundholm, N., 2002. First report of Pseudo-nitzschia calliantha Lundholm, Moestrup and Hasle 2003, a new potentially toxic species from Turkish coasts. EU Journal of Fisheries and Aquatic Sciences, 19, 479-483. http://dx.doi.org/10.12714/egejfas.2002.19.3.5000157174 http://dergipark.ulakbim.gov.tr/egejfas/article/view/5000157174

Benović, A., Fonda Umani, S., Malej, A. Specchi, M., 1984. Net-zooplankton biomass of the Adriatic Sea. Mar. Biol. 79, 209-218. https://doi.org/10.1007/BF00951829 https://link.springer.com/article/10.1007/BF00951829

Benner, R., Herndl, G. J., 2011. Bacterially derived dissolved organic matter in the microbial carbon pump, in: Jiao N., Azam, F., Sanders, S. (Eds), Microbial carbon pump in the ocean. Science/AAAS Publishers Online, pp. 46-48. https://doi.org/10.1126/science.opms.sb0001 http://www.sciencemag.org/site/products/microbialpump/

Bergamasco, A., Malanotte-Rizzoli, P., 2010. The circulation of the Mediterranean Sea: a historical review of experimental investigations. Adv. Ocean. Limn., 1, 11-28. https://doi.org/10.1080/19475721.2010.491656 https://www.tandfonline.com/doi/abs/10.1080/19475721.2010.491656 
Black Sea Commission, 2008. State of the environment of the Black Sea (2001-2006/7). Publications of the Commission on the Protection of the Black Sea against Pollution (BSC), 3. https://www.eea.europa.eu/data-and-maps/indicators/chlorophyll-in-transitionalcoastal-and-2/black-sea-commission-2008.-state

Borja, A., Bricker, S.B., Dauer, D.M., Demetriades, N.T., Ferreira, J.G., Forbes, A.T., Hutchings, P., Jia, X., Kenchington, R., Marques, J.C., Zhu, C., 2008. Overview of integrative tools and methods in assessing ecological integrity in estuarine and coastal systems worldwide. Mar. Poll. Bull. 56, 1519-1537. https://doi.org/10.1016/j.marpolbul.2008.07.005 https://www.sciencedirect.com/science/article/pii/S0025326X08003573

Borme, D., Tirelli, V., Brandt, S. B., Fonda Umani, S., Arneri, E., 2009. Diet of Engraulis encrasicolus in the northern Adriatic Sea (Mediterranean): ontogenetic changes and feeding selectivity. Mar. Ecol. Prog. Ser. 392, 193-209. doi: 10.3354/meps08214 https://www.int-res.com/abstracts/meps/v392/p193-209/

Bradshaw, J.K., Snyder, B.J., Oladeinde, A., Spidle, D., Berrang, M.E., Meinersmann, R.J., Oakley, B., Sidle, R.C., Sullivan, K., Molina, M., 2016. Characterizing relationships among fecal indicator bacteria, microbial source tracking markers, and associated waterborne pathogen occurrence in stream water and sediments in a mixed land use watershed. Water Res. 101, 498-509. https://doi.org/10.1016/j.watres.2016.05.014 https://www.sciencedirect.com/science/article/pii/S0043135416303323

Calvo-Díaz, A., Morán X.A.G., Suárez, L.A., 2008. Seasonality of pico-phytoplankton chlorophyll a and biomass in the central Cantabrian Sea, southern Bay of Biscay. J. Mar. Syst. 72, 271-281. https://doi.org/10.1016/j.jmarsys.2007.03.008 https://www.sciencedirect.com/science/article/pii/S0924796307002527

Carletti, A., Heiskanen, A.S., 2009. Water Framework Directive intercalibration technical report. Part 3: Coastal and Transitional waters. JRC-IES EUR 23838 EN/3. https://www.eea.europa.eu/data-and-maps/indicators/chlorophyll-in-transitionalcoastal-and-2/carletti-a-heiskanen-as.-2009.

Carlson, C.A, Del Giorgio, P.A, Herndl, G.J. 2007. Microbes and the dissipation of energy and respiration: from cells to ecosystems. Oceanography. 20, 89-100. https://doi.org/10.5670/oceanog.2007.52 https://tos.org/oceanography/article/microbes-and-the-dissipation-of-energy-andrespiration-from-cells-to-ecosys

Caroppo, C., 2015. Ecology and biodiversity of picoplanktonic cyanobacteria in coastal and brackish environments. Biodiv. Conserv. 24, 949-71. https://doi.org/10.1007/s10531-015-0891-y https://link.springer.com/article/10.1007/s10531-015-0891-y

Carstensen, J., Sánchez-Camacho, M., Duarte, C. M., Krause-Jensen, D., Marba, N., 2011. Connecting the dots: responses of coastal ecosystems to changing nutrient concentrations. Environ. Sci. Technol. 45, 9122-9132. https://doi.org/10.1021/es202351y https://pubs.acs.org/doi/abs/10.1021/es202351y

Caruso, G., Denaro, R., Genovese, M., Giuliano, L., Mancuso, M. Yakimov, M., 2004. New methodological strategies for detecting bacterial indicators. Chem. Ecol. 20, 167-81. https://doi.org/10.1080/02757540410001690333 https://www.tandfonline.com/doi/abs/10.1080/02757540410001690333

Caruso, G., Azzaro, M., Caroppo, C., Decembrini, F., Monticelli, L.S., Leonardi, M., Maimone, G., Zaccone, R., La Ferla, R., 2016a. Microbial community and its potential as descriptor of environmental status. ICES J. Mar. Sci. 73, 2174-2177. https://doi.org/10.1093/icesjms/fsw101 https://academic.oup.com/icesjms/article/73/9/2174/2199434 
Caruso, G., La Ferla, R., Azzaro, M., Zoppini, A., Marino, G., Petochi, T., Corinaldesi, C., Leonardi, M., Zaccone, R., Fonda Umani, S. and Caroppo, C., 2016b. Microbial assemblages for environmental quality assessment: Knowledge, gaps and usefulness in the European Marine Strategy Framework Directive. Crit. Rev. Microbiol. 42, 883904. https://doi.org/10.3109/1040841X.2015.1087380 https://www.ncbi.nlm.nih.gov/pubmed/26585708

Carvalho, L., Poikane, S., Solheim, A.L., Phillips, G., Borics, G., Catalán, J., De Hoyos, C., Drakare, S., Dudley, B.J., Järvinen, M. and Laplace-Treyture, C., 2013. Strength and uncertainty of phytoplankton metrics for assessing eutrophication impacts in lakes. Hydrobiologia 704, 127-140 https://doi.org/10.1007/s10750-012-1344-1 https://link.springer.com/article/10.1007/s10750-012-1344-1

CIESM, W., 2001. Gelatinous zooplankton outbreaks: theory and practice. In CIESM: The Mediterranean Science Commission, Workshop Series, no 14, CIESM, Monaco. http://www.ciesm.org/online/monographs/Naples.html

Cochrane, S.K.J., Connor, D.W., Nilsson, P., Mitchell, I., Reker, J., Franco, J., Valavanis, V., Moncheva, S., Ekebom, J., Nygaard, K. Santos, R.S., 2010. Marine Strategy Framework Directive-Task Group 1 Report Biological Diversity, Zampoukas N. (Ed.). Office for Official Publications of the European Communities, EUR, 24337, p.110. http://dx.doi.org/10.2788/86653 https://ec.europa.eu/jrc/en/publication/eur-scientific-and-technical-researchreports/marine-strategy-framework-directive-task-group-1-report-biologicaldiversity

Coll, M., Piroddi, C., Steenbeek, J., Kaschner, K., Lasram, F.B.R., Aguzzi, J., Ballesteros, E., Bianchi, C.N., Corbera, J., Dailianis, T. and Danovaro, R., 2010. The Biodiversity of the Mediterranean Sea: Estimates, Patterns, and Threats. PLoS ONE 5(8), e11842. https://doi.org/10.1371/journal.pone.0011842 http://journals.plos.org/plosone/article?id=10.1371/journal.pone.0011842

Cozzoli, F., Stanca, E., Selmeczy, G.B., Francé, J., Varkitzi, I., Basset, A., 2017. Sensitivity of phytoplankton metrics to sample-size: A case study on a large transitional water dataset (WISER). Ecol. Indic. 82, 558-573. https://doi.org/10.1016/j.ecolind.2017.07.022 https://www.sciencedirect.com/science/article/pii/S1470160X17304363

Cozzoli, F., Basset A., 2017. Electronic catalogue of biodiversity indicators, in: Paramana et al. (Eds), Final Report on MSFD biodiversity descriptors/indicators for the Mediterranean -A comparison of targets and associated indicators \& Proposal of a common set of biodiversity indicators for the Mediterranean Sea. Deliverable 1.3, ActionMed EU project

http://actionmed.eu/wp-content/uploads/2017/12/D1.3-ActionMed-MSFDBiodiversity-descriptors-indicators.pdf

Cozzoli F., Reizopoulou S., Paramana T., Katsouras G., Chalkiadaki O., Ladakis M., Dassenakis M., Alemany F., Deudero S., Orlando M., Mavric B., Papatheochari T., Sauzade D., Simboura N., Niavis S., Coccossis H., Streftaris N., Giannoudi L., Pagou K., Varkitzi I., Basset A., 2016. Final Activity 1 Report. Deliverable 1.4, ActionMed EU project http://actionmed.eu/wp-content/uploads/2017/10/D1.4_ActionMed_Manual.pdf

Davidson, K., Gowen, R. J., Harrison, P. J., Fleming, L. E., Hoagland, P., Moschonas, G., 2014. Anthropogenic nutrients and harmful algae in coastal waters. J. Environ. Manage. 146, 206-216. https://doi.org/10.1016/j.jenvman.2014.07.002 https://www.sciencedirect.com/science/article/pii/S030147971400334X

Directive 2008/56/EC of the European Parliament and of the Council of 17 June 2008 establishing a framework for community action in the field of marine environmental policy (Marine Strategy Framework Directive) (Text with EEA relevance). https://eur-lex.europa.eu/legal-content/EN/TXT/?uri=CELEX\%3A32008L0056 
1030

1031

1032

1033

1034

1035

1036

1037

1038

1039

1040

1041

1042

1043

1044

1045

1046

1047

1048

1049

1050

1051

1052

1053

1054

1055

1056

1057

1058

1059

1060

1061

1062

1063

1064

1065

1066

1067

1068

1069

1070

1071

1072

1073

1074

1075

1076

1077

1078

1079

1080

1081

1082

1083

D'Ortenzio, F., Ribera d'Alcalà, M., 2009. On the trophic regimes of the Mediterranean Sea: a satellite analysis. Biogeosciences. 6, 139-148. https://doi.org/10.5194/bg-6139-2009 https://www.biogeosciences.net/6/139/2009/

Domingues, R.B., Barbosa, A., Galvão, H., 2008. Constraints on the use of phytoplankton as a biological quality element within the Water Framework Directive in Portuguese waters. Mar. Pollut. Bull. 56, 1389-1395. https://doi.org/10.1016/j.marpolbul.2008.05.006 https://www.sciencedirect.com/science/article/pii/S0025326X08002671

Duarte, C. M., Regaudie-de-Gioux, A., Arrieta, J. M., Delgado-Huertas, A., Agustí, S., 2013. The oligotrophic ocean is heterotrophic. Ann. Rev. Mar. Sci. 5, 551-569. https://doi.org/10.1146/annurev-marine-121211-172337

https://www.ncbi.nlm.nih.gov/pubmed/22809189

European Commission 2012. Guidance for 2012 reporting under the Marine Strategy Framework Directive, using the MSFD database tool. Version 1.0. DG Environment, Brussels. https://circabc.europa.eu/sd/a/439e849f-2710-452d-9c8d10322a17f141/1206_MSFD\%20Reporting\%20Guidance_Final.doc

European Commission Decision 2013/480/EU. Commission Decision of 20 September 2013 establishing, pursuant to Directive 2000/60/EC of the European Parliament and of the Council, the values of the Member State monitoring system classifications as a result of the intercalibration exercise and repealing Decision 2008/915/EC (notified under document C(2013) 5915) Text with EEA relevance. https://eur-lex.europa.eu/legal-content/EN/TXT/?uri=CELEX\%3A32013D0480

European Commission Decision 2018/229/EU: Commission Decision (EU) 2018/229 of 12 February 2018 establishing, pursuant to Directive 2000/60/EC of the European Parliament and of the Council, the values of the Member State monitoring system classifications as a result of the intercalibration exercise and repealing Commission Decision 2013/480/EU (notified under document C (2018) 696) Text with EEA relevance.

https://eur-lex.europa.eu/legalcontent/EN/TXT/?uri=uriserv\%3AOJ.L_.2018.047.01.0001.01.ENG

Facca, C., Sfriso, A., 2009. Phytoplankton in a transitional ecosystem of the Northern Adriatic Sea and its putative role as an indicator for water quality assessment. Mar. Ecol. 30, 462-479. doi:10.1111/j.1439-0485.2009.00347.x https://onlinelibrary.wiley.com/doi/abs/10.1111/j.1439-0485.2009.00347.x

Ferreira, J.G., Andersen, J.H., Borja, A., Bricker, S.B., Camp, J., Cardoso da Silva, M., Garcés, E., Heiskanen, A.-S., Humborg, C., Ignatiades, L., Lancelot, C., Menesguen, A., Tett, P., Hoepffner, N., Claussen, U., 2011. Overview of eutrophication indicators to assess environmental status within the European Marine Strategy Framework Directive. Est. Coast. Shelf Sci. 93, 117-131. https://doi.org/10.1016/j.ecss.2011.03.014 https://www.sciencedirect.com/science/article/pii/S0272771411001077

Fleming-Lehtinen, V., Andersen, J.H., Carstensen, J., Łysiak-Pastuszak, E., Murray, C., Pyhälä, M., Laamanen, M., 2015. Recent developments in assessment methodology reveal that the Baltic Sea eutrophication problem is expanding. Ecol. Indic. 48, 380388. https://doi.org/10.1016/j.ecolind.2014.08.022 https://www.sciencedirect.com/science/article/pii/S1470160X1400377X

Foden, J., Devlin, M., Mills, D., Malcolm, S., 2011. Searching for undesirable disturbance: an application of the OSPAR eutrophication assessment method to marine waters of England and Wales. Biogeochemistry. 106, 157-175. https://doi.org/10.1007/s10533-010-9475-9 https://link.springer.com/article/10.1007/s10533-010-9475-9

Garcés, E., Camp, J., 2012. Habitat changes in the Mediterranean sea and the consequences for harmful algal blooms formation, in: Stambler N. (Ed.), Life in the 
Mediterranean Sea: A Look at Habitat Changes. Nova Science Publishers, pp. 519541.

https://www.novapublishers.com/catalog/product_info.php?products_id=21851

Gasol, J.M., Pinhassi, J., Alonso-Sáez, L., Ducklow, H., Herndl, G.J., Koblĩ zek, M., Labrenz, M., Luo, Y., Morán, X.A.G., Reinthaler, T. and Simon, M., 2008.Towards a better understanding of microbial carbon flux in the sea. Aquat. Microb. Ecol. 53, 21-38. https://doi.org/10.3354/ame01230 https://www.int-res.com/abstracts/ame/v53/n1/p21-38/

Gieskes, W.W.C., Leterme, S.C., Peletier, H., Edwards, M., Reid, P.C., 2007. Phaeocystis colony distribution in the North Atlantic Ocean since 1948, and interpretation of long-term changes in the Phaeocystis hotspot in the North Sea. Biogeochemistry. 83, 49-60. https://doi.org/10.1007/s10533-007-9082-6

https://link.springer.com/article/10.1007/s10533-007-9082-6

Giovanardi, F., Francé, J., Mozetič, P., Precali, R., 2018. Development of ecological classification criteria for the Biological Quality Element phytoplankton for Adriatic and Tyrrhenian coastal waters by means of chlorophyll a (2000/60/EC WFD). Ecol. Indic. 93, 316-332.

Glockner, F.O, Stal, L.J, Sandaa, R.A, Gasol, J.M., O’Gara, F., Hernandez, F., Labrenz, M., Stoica, E., Varela, M.M., Bordalo, A., Pitta, P., 2012. Marine microbial diversity and its role in ecosystem functioning and environmental change. Marine Board Position Paper 17. Calewaert, J.B., McDonough, N. (Eds.). Marine Board-ESF, Ostend, Belgium. http://www.marineboard.eu/publication/marine-microbial-diversity-and-its-roleecosystem-functioning-and-environmental-change

Gonçalves, J., Gutiérrez-Aguirre, I, Balasubramanian, M N, Zagorščak, M, Ravnikar, M, Turk, V., 2018. Surveillance of human enteric viruses in coastal waters using concentration with methacrylate monolithic supports prior to detection by RTqPCR. Mar. Poll. Bull. 128, 307-317. https://doi.org/10.1016/j.marpolbul.2018.01.040 https://www.sciencedirect.com/science/article/pii/S0025326X18300511

Gorokhova, E., Lehtiniemi, M., Postel, L., Rubene, G., Amid, C., Lesutiene, J., Uusitalo, L., Strake, S. Demereckiene, N., 2016. Indicator properties of Baltic Zooplankton for classification of environmental status within Marine Strategy Framework Directive. PloS one, 11(7), p.e0158326. https://doi.org/10.1371/journal.pone.0158326 http://journals.plos.org/plosone/article?id=10.1371/journal.pone.0158326 Håkanson, L., Eklund, J.M., 2010. Relationships Between Chlorophyll, Salinity, Phosphorus, and Nitrogen in Lakes and Marine Areas. JCR 26, 412-423. https://doi.org/10.2112/08-1121.1 http://www.jcronline.org/doi/full/10.2112/08-1121.1?=

Hansell, D. A., Carlson, C. A., Repeta, D. J., Schlitzer, R., 2009. Dissolved organic matter in the ocean: A controversy stimulates new insights. Oceanography. 22, 202-211. https://doi.org/10.5670/oceanog.2009.109 https://tos.org/oceanography/article/dissolved-organic-matter-in-the-ocean-acontroversy-stimulates-new-insights

Hansson, M., Hakansson, B., 2007. The Baltic Algae Watch System - a remote sensing application for monitoring cyanobacterial blooms in the Baltic Sea. J. Appl. Rem. Sens. 1(1):011507. https://doi.org/10.1117/1.2834769 http://spie.org/Publications/Journal/10.1117/1.2834769

Harding, L.W., Batiuk, R.A., Fisher, T.R., Gallegos, C.L., Malone, T.C., Miller, W.D., Mulholland, M.R., Paerl, H.W., Perry, E.S., Tango, P., 2013. Scientific Bases for Numerical Chlorophyll Criteria in Chesapeake Bay. Estuar. Coasts. 37, 134-148. https://doi.org/10.1007/s12237-013-9656-6 https://link.springer.com/article/10.1007/s12237-013-9656-6

HELCOM, 2012. Checklist of Baltic Sea macro-species. Baltic Sea Environment Proceedings 130. 
http://www.helcom.fi/Lists/Publications/BSEP130.pdf

HELCOM HOD 48-2015 (outcome para 3.63, Annex 4) agreed on the concepts for the thresholds values of 'Zooplankton mean size and total stock' noting that no quantitative values had been proposed. https://portal.helcom.fi/meetings/HOD\%2048-2015189/MeetingDocuments/Outcome_HOD\%2048-2015.pdf

HELCOM, 2017a. Diatom/Dinoflagellate index. HELCOM pre-core indicator report. Online. 16 Nov 2017. http://www.helcom.fi/baltic-sea-trends/indicators/Diatomdinoflagellate-index

HELCOM, 2017b. Status of development of pre-core and candidate indicators (4J-7). Working Group on the State of the Environment and Nature Conservation. 15-19 May 2017. https://portal.helcom.fi/meetings/STATE\%20\%20CONSERVATION\%206-2017-412/MeetingDocuments/4J7\%20Status\%20of\%20development\%20of\%20precore $\% 20$ and $\% 20$ candidate $\% 20$ indicators.pdf

HELCOM, 2017c. Zooplankton mean size and total stock. HELCOM core indicator report. Online. 20 Nov 2017, http://www.helcom.fi/baltic-seatrends/indicators/zooplankton-mean-size-and-total-stock-(MSTS)/ ISSN 23432543

HELCOM, 38-2017. Outcome para 4.19, Annex 5 adopted the threshold values for the core indicators "Cyanobacterial blooms index". https://portal.helcom.fi/meetings/HELCOM\%2038-2017401/MeetingDocuments/Outcome\%20of\%20HELCOM\%2038-2017.pdf

Höglander, H., Karlson, B., Johansen, M., Walve, J., Andersson, A., 2013. Overview of coastal phytoplankton indicators and their potential use in Swedish waters. Deliverable 3.3-1, WATERS Report no. 2013: 5. Havsmiljöinstitutet, Sweden. https://gupea.ub.gu.se/handle/2077/37081

Ignatiades L., Gotsis-Skretas O. 2010. A Review on Toxic and Harmful Algae in Greek Coastal Waters (E. Mediterranean Sea). Toxins. 2, 1019-1037. https://doi.org/10.3390/toxins2051019 http://www.mdpi.com/2072-6651/2/5/1019

Jiao, N., Azam, F., 2011. Microbial carbon pump and its significance for carbon sequestration in the ocean, in: Jiao N., Azam, F., Sanders, S. (Eds), Microbial carbon pump in the ocean. Science/AAAS Publishers Online, pp. 43-45.

Kaiser, M.J., Attrill, M.J., Jennings, S., Thomas, D.N., Barnes, D.K.A., Brierley, A.S., Hiddink, J.G., Kaartokallio, H., Polunin, N.V.C., Raffaelli, D.G., 2011. Marine Ecology. Processes, Systems, and Impacts, second ed. Oxford University Press, New York. https://global.oup.com/academic/product/marine-ecology9780199227020?cc=gr\&lang=en\&

Kaitala, S., Hällfors, S., 2008. Cyanobacteria Bloom Index. HELCOM Baltic Sea Environment Fact Sheets. Online. 20 Nov 2017, http://www.helcom.fi/baltic-seatrends/environment-fact-sheets/eutrophication/cyanobacteria-bloom-index

Kogovšek,T., Bogunović,B. Malej, A. 2010. Recurrence of bloom forming scyphomedusae: Wavelet analysis of a 200 year time series. Hydrobiologia. 645, 81- 96. doi:10.1007/s10750L010L0217L8. https://link.springer.com/article/10.1007/s10750-010-0217-8

Koukaras, K., Nikolaidis, G., 2004. Dinophysis blooms in Greek coastal waters (Thermaikos Gulf, NW Aegean Sea). J. Plank. Res. 26, 445-457. https://doi.org/10.1093/plankt/fbh042 https://academic.oup.com/plankt/article/26/4/445/1435527

Kršinić, F., 2010. Tintinnids (Tintinnida, Choreotrichia, Ciliata) in the Adriatic Sea, Mediterranean. Part 1. Taxonomy. Monograph, Institute of Oceanography and Fisheries Split, Croatia.

http://www.izor.hr/web/guest/monograph-krsinic 
Kršinić F. and Kršinić A. 2012. Radiolarians in Adriatic Sea plankton (Eastern Mediterranean). Acta Adriatica 53 (2): 189-212. http://jadran.izor.hr/acta/eng/v53_2_3.htm

Kruskopf, M., Flynn, K.J., 2006. Chlorophyll content and fluorescence responses cannot be used to gauge reliably phytoplankton biomass, nutrient status or growth rate. New Phytol. 169, 525-536. https://doi.org/10.1111/j.1469-8137.2005.01601.x https://nph.onlinelibrary.wiley.com/doi/abs/10.1111/j.1469-8137.2005.01601.x Laamanen, M., Kuosa, H. 2005: Annual variability of the biomass and heterocysts of the N2-fixing cyanobacterium Aphanizomenon flos-aquae in the Baltic Sea with reference to Anabaena spp. and Nodularia spumigena. Boreal. Environ. Res. 10, 1930.

http://www.borenv.net/BER/pdfs/ber10/ber10-019.pdf

La Ferla, R., Maimone, G., Caruso, G., Azzaro, F., Azzaro, M., Decembrini, F., Cosenza, A., Leonardi, M. and Paranhos, R., 2014. Are prokaryotic cell shape and size suitable to ecosystem characterization? Hydrobiologia 726, 65-80. https://doi.org/10.1007/s10750-013-1752-x https://link.springer.com/article/10.1007/s10750-013-1752-x

Liang, L., Goh, S.G., Vergara, G.G.R.V., Fang, H.M., Rezaeinejad, S., Chang, S.Y., Bayen, S., Lee, W.A., Sobsey, M.D., Rose, J.B., Gin, K.Y.H., 2015. Alternative fecal indicators and their empirical relationships with enteric viruses, Salmonella enterica, and Pseudomonas aeruginosa in surface waters of a tropical urban catchment. Appl. Environ. Microbiol. 81, 850-860. http://dx.doi.org/10.1128/AEM.02670-14 http://aem.asm.org/content/81/3/850.full

Lugoli, F., Garmendia, M., Lehtinen, S., Kauppila, P., Moncheva, S., Revilla, M., Roselli, L., Slabakova, N., Valencia, V., Dromph, K.M. and Basset, A., 2012. Application of a new multi-metric phytoplankton index to the assessment of ecological status in marine and transitional waters. Ecol. Indic. 23, 338-355. https://doi.org/10.1016/j.ecolind.2012.03.030 https://www.sciencedirect.com/science/article/pii/S1470160X12001380

Luna, G.M., 2015. Diversity of marine microbes in a changing Mediterranean Sea. Rend. Fis. Acc. Lincei 26: 49-58 https://doi.org/10.1007/s12210-014-0333-x https://link.springer.com/article/10.1007/s12210-014-0333-x

Magurran, A. E., Mc Gill, B. J., 2011. Biological diversity: frontiers in measurement and assessment. Oxford University Press. https://global.oup.com/academic/product/biological-diversity9780199580675?cc=gr\&lang=en\&

Mangoni, O., Modigh, M., Mozetič, P., Bergamasco, A., Rivaro, P., S, V., 2008. Structure and photosynthetic properties of phytoplankton assemblages in a highly dynamic system, the Northern Adriatic Sea. Estuar., Coast. Shelf Sci. 77, 633-644. https://doi.org/10.1016/j.ecss.2007.10.023 https://www.sciencedirect.com/science/article/pii/S0272771407004908

MARBEF definition of keystone species in Marine Biodiversity and Ecosystem Functioning EU Network of Excellence, http://www.marbef.org/wiki/Keystone_species

Markogianni, V., Varkitzi, I., Pagou, K., Pavlidou, A., Dimitriou, E., 2017. Nutrient flows and related impacts between a Mediterranean river and the associated coastal area. Cont. Shelf Res. 134, 1-14. https://doi.org/10.1016/j.csr.2016.12.014 https://www.sciencedirect.com/science/article/pii/S0278434316303132

Menge, B.A., Iles, A.C., Freidenburg, T.L., 2013. Keystone Species, in: Levin, S.A. (Ed.), Encyclopedia of Biodiversity, 4, second edition, Academic Pres, pp. 442-457.

Morán, X.A.G., Alonso-Sáez, L., Nogueira, E., Ducklow, H.W., González, N., López-Urrutia, Á., Díaz-Pérez, L., Calvo-Díaz, A., Arandia-Gorostidi, N. and Huete-Stauffer, T.M., 2015. More smaller bacteria in response to ocean's warming? Proc. R. Soc. B. 282, 20150371. https://doi.org/10.1098/rspb.2015.0371 
Mozetič, P., Cangini, M., Francé, J., Bastianini, M., Bernardi Aubry, F., Bužančić, M., Cabrini, M., Cerino, F., Čalić, M., D'adamo, R., Drakulović, D., Finotto, S., Fornasaro, D., Grilli, F., Kraus, R., Kužat, N., Marić Pfannkuchen, D., Ninčević Gladan, Ž., Pompei, M., Rotter, A., Servadei, I., Skejić, S., 2017. Phytoplankton diversity in Adriatic ports: Lessons from the port baseline survey for the management of harmful algal species. Mar. Poll. Bull., https://doi.org/10.1016/j.marpolbul.2017.12.029 https://www.sciencedirect.com/science/article/pii/S0025326X17310561

Mozetič, P., France, J., Kogovšek, T., Talaber, I., Malej, A., 2012. Plankton trends and community changes in a coastal sea (northern Adriatic): Bottom-up vs. top-down control in relation to environmental drivers. Est. Coast. Shelf Sci. 115, 138-148. https://doi.org/10.1016/j.ecss.2012.02.009 https://www.sciencedirect.com/science/article/pii/S0272771412000352

Nikolioudakis, N., Isari, S., Pitta, P., Somarakis, S. 2012. Diet of sardine Sardina pilchardus: an 'end-to-end' field study. Mar. Ecol. Prog. Ser. 453, 173-188. https://doi.org/10.3354/meps09656 https://www.int-res.com/abstracts/meps/v453/p173-188/

Ninčević-Gladan, Ž., Bužanić, M., Kušpilić, G., Grbec, B., Matijević, S., Skejić, S., Marasović, I., Morović, M. 2015. The response of phytoplankton community to anthropogenic pressure gradient in the coastal waters of the eastern Adriatic Sea. Ecol. Indic. 56, 106-115. https://doi.org/10.1016/j.ecolind.2015.03.018 https://www.sciencedirect.com/science/article/pii/S1470160X15001429

Öberg, J., 2016. Cyanobacteria blooms in the Baltic Sea. HELCOM Baltic Sea Environment Fact Sheets 2016. Online. 20 Nov 2017. http://helcom.fi/baltic-seatrends/environment-fact-sheets/eutrophication/cyanobacterial-blooms-in-thebaltic-sea/

Ojaveer, H., Jaanus, A., MacKenzie, B.R., Martin, G., Olenin, S., Radziejewska, T., Telesh, I., Zettler, M.L. and Zaiko, A., 2010. Status of biodiversity in the Baltic Sea. PLoS one, 5(9), p.e12467. https://doi.org/10.1371/journal.pone.0012467 http://journals.plos.org/plosone/article?id=10.1371/journal.pone.0012467

Orlando Bonaca, M., Lipej, L., Malej, A., Francé, J., Čermelj, B., Bajt, O., Kovač, N., Mavrič, B., Mozetič, P., Ramšak, A., Kogovšek, T., Malačič, V., 2012a. Oblikovanje okoljskih ciljnih vrednosti Poročilo za člen 10 Okvirne direktive o morski strategiji: zaključno poročilo 2012. National Institute of Biology - Marine Biology Station, Piran, p. 49.

Orlando Bonaca, M., Lipej, L., Malej, A., et al., 2012b. Določanje dobrega okoljskega stanja. Poročilo za člen 9 Okvirne direktive o morski strategiji: zaključno poročilo 2012. National Institute of Biology - Marine Biology Station, Piran, p. 177.

Orlando Bonaca, M., Lipej, L., Malej, A., et al., 2012c. Začetna presoja stanja slovenskega morja. Poročilo za člen 8 Okvirne direktive o morski strategiji: zaključno poročilo 2012. National Institute of Biology - Marine Biology Station, Piran, p. 345.

OSPAR Commission, 2017. Eutrophication Status of the OSPAR Maritime Area. Third Integrated Report on the Eutrophication Status of the OSPAR Maritime Area. $164 \mathrm{pp}$. https://www.ospar.org/documents?v=37502

Pachés, M., Romero, I., Hermosilla, Z., Martinez-Guijarro, R., 2012. PHYMED: An ecological classification system for the Water Framework Directive based on phytoplankton community composition. Ecol. Indic. 19, 15-23. https://doi.org/10.1016/j.ecolind.2011.07.003 https://www.sciencedirect.com/science/article/pii/S1470160X11002093

Palomera, I., Olivar, M.P., Salat, J., Sabatés, A., Coll, M., García, A., Morales-Nin, B. 2007. Small pelagic fish in the NW Mediterranean Sea: An ecological review. Prog. Oceanogr. 74, 377-396. https://doi.org/10.1016/i.pocean.2007.04.012 https://www.sciencedirect.com/science/article/pii/S0079661107000717 Paramana T.., Katsouras G., Chalkiadaki O., Ladakis M., Dassenakis M., Reizopoulou S., Basset A., Cozzoli F., Alemany F., Alomar C., Orlando Bonaca M., Mavric B., 
Papatheochari T., Sauzade D., Simboura N., Niavis S., Coccossis H., Streftaris N., Giannoudi L., Pagou K., Varkitzi I., 2017. Final Report on MSFD biodiversity descriptors/indicators for the Mediterranean -A comparison of targets and associated indicators \& Proposal of a common set of biodiversity indicators for the Mediterranean Sea. Deliverable 1.3, ActionMed EU project

http://actionmed.eu/wp-content/uploads/2017/12/D1.3-ActionMed-MSFDBiodiversity-descriptors-indicators.pdf

Pedrós-Alió C., 2006. Marine microbial diversity: can it be determined? Trends Microbiol. 14, 257-63. https://doi.org/10.1016/j.tim.2006.04.007 https://www.sciencedirect.com/science/article/pii/S0966842X06000989

Pomeroy L.R., Williams P.J.L.B, Azam F., Hobbie J.E., 2007. The microbial loop. Oceanography 20, 28-33. https://doi.org/10.5670/oceanog.2007.45 https://tos.org/oceanography/article/the-microbial-loop

Pugnetti, A., Bastianini, M., Acri, F., Bernardi Aubry, F., Bianchi, F., Boldrin, A., Socal, G., 2007. Comunita' fitoplanctoniche e climatologia nell'Adriatico Settentrionale, in: Carli, B., Gavaretta, G., Colacino, N., Fuzzi, S. (Eds.), Clima e cambiamenti climatici: le attivita' di ricerca del CNR. CNR, Roma, pp. 551-556.

Robinson C., Williams P.J. le B., 2005. Respiration and its measurements in surface marine waters, in: Del Giorgio P.A, Williams P.J le B. (Eds.), Respiration in aquatic systems. Oxford University Press, New York, pp. 147-180.

Romero, I., Pachés, M., Martínez-Guijarro, R., Ferrer, J., 2013. Glophymed: An index to establish the ecological status for the Water Framework Directive based on phytoplankton in coastal waters. Mar. Pollut. Bull. 75, 218-223. https://doi.org/10.1016/j.marpolbul.2013.07.028 https://www.sciencedirect.com/science/article/pii/S0025326X13004153

Sabetta, L., Vadrucci, M.R., Fiocca, A., Stanca, E., Mazziotti, C., Ferrari, C., Cabrini, M., Kongjka, E., Basset, A., 2008. Phytoplankton size structure in transitional water ecosystems: a comparative analysis of descriptive tools. Aquat. Conserv. 18, S76S87. https://doi.org/10.1002/aqc. 954 https://onlinelibrary.wiley.com/doi/abs/10.1002/aqc.954

Salazar, G., Cornejo-Castillo, F.M., Benítez-Barrios, V., Fraile-Nuez, E., Álvarez-Salgado, X.A., Duarte, C.M., Gasol, J.M. and Acinas, S.G., 2016. Global diversity and biogeography of deep-sea pelagic prokaryotes. ISME J. 10, 596. https://doi.org/10.1038/ismej.2015.137 https://www.nature.com/articles/ismej2015137

McQuatters-Gollop, A., Edwards, M., Reid, P.C., Johns, D., 2010. Healthy and biologically diverse seas evidence group technical report series: evaluation and gap analysis of current and potential indicators for plankton. United Kingdom Marine Monitoring \& Assessment Strategy (UKMMAS). Joint Nature Conservation Committee (JNCC), Peterborough, Cambridge shire. http://jncc.defra.gov.uk/pdf/WEB_MarinePlanktonSahfosIndicators.pdf

Serranito, B., Aubert, A., Stemmann, L., Rossi, N., Jamet, J.L., 2016. Proposition of indicators of anthropogenic pressure in the Bay of Toulon (Mediterranean Sea) based on zooplankton time-series. Cont. Shelf Res. 121, 3-12. https://doi.org/10.1016/j.csr.2016.01.016 https://www.sciencedirect.com/science/article/pii/S027843431630019X Smith C., Papadopoulou N., Sevastou K., Franco A., Teixeira H., Piroddi C., Katsanevakis S., Fürhaupter K., Beauchard O., Cochrane S., Ramsvatn S., Feral J.P., Chenuil A., David R., Kiriakopoulou N., Zaiko A., Moncheva S., Stefanova K., Churilova T., Kryvenko O., 2014. Report on identification of keystone species and processes across regional seas. Deliverable 6.1, DEVOTES Project. http://www.devotes-project.eu/wp-content/uploads/2014/07/DEVOTES-D6-1Keystones.pdf 
Siokou-Frangou, I., Christaki, U., Mazzocchi, M.G., Montresor, M., Ribera d'Alcalá, M., Vaqué, D., Zingone, A., 2010. Plankton in the open Mediterranean Sea: a review. Biogeosciences 7, 1543-1586. https://doi.org/10.5194/bg-7-1543-2010 https://www.biogeosciences.net/7/1543/2010/bg-7-1543-2010.html

Southwood, T.R.E., Henderson, P.A., 2009. Ecological methods. John Wiley \& Sons.

Spatharis, S., Tsirtsis, G., 2010. Ecological quality scales based on phytoplankton for the implementation of Water Framework Directive in the Eastern Mediterranean. Ecol. Indic. 10, 840-847. https://doi.org/10.1016/j.ecolind.2010.01.005 https://www.sciencedirect.com/science/article/pii/S1470160X10000063

Stanca E., Cozzoli F., Selmeczy G. B.,France J. Varkitzi I, Basset A., 2017. Case study 8: Ability of phytoplankton metrics and indices in discriminating natural vs. anthropogenic variability: Accuracy, in: Paramana T. et al., 2017 (Eds.), Final Report on MSFD biodiversity descriptors/indicators for the Mediterranean-A comparison of targets and associated indicators \& Proposal of a common set of biodiversity indicators for the Mediterranean Sea." Deliverable 1.3, ActionMed EU project http://actionmed.eu/wp-content/uploads/2017/12/D1.3-ActionMed-MSFDBiodiversity-descriptors-indicators.pdf

Stomp, M., Huisman, J., Vörös, L., Pick, F.R., Laamanen, M., Haverkamp, T. and Stal, L.J., 2007. Colourful coexistence of red and green picocyanobacteria in lakes and seas. Ecol. Lett. 10, 290-298. https://doi.org/10.1111/j.1461-0248.2007.01026.x https://www.ncbi.nlm.nih.gov/pubmed/17355568

Sunagawa, S., Coelho, L.P., Chaffron, S., Kultima, J.R., Labadie, K., Salazar, G., Djahanschiri, B., Zeller, G., Mende, D.R., Alberti, A. and Cornejo-Castillo, F.M., 2015. Structure and function of the global ocean microbiome.Science, 348(6237), p.1261359. https://doi.org/10.1126/science.1261359 http://science.sciencemag.org/content/348/6237/1261359

Teixeira, H., Berg, T., Fürhaupter, K., Uusitalo, L., Papadopoulou, N., Bizsel, K.C., Cochrane, S., Churilova, T., Heiskanen, A.-S., Uyarra, M.C., Zampoukas, N., Borja, A., Akcali, B., Andersen, J.H., Beauchard, O., Berzano, M., Bizsel, N., Bucas, M., Camp, J., Carvalho, S., Flo, E., Garcés, E., Herman, P.M.J., Katsanevakis, S., Kavcioglu, R., KrauseJensen, D., Kryvenko, O., Lynam, C.P., Mazik, K., Moncheva, S., Neville, S., Ozaydinli, M., Pantazi, M., Patricio, J., Piroddi, C., Queirós, A.M., Ramsvatn, S., Rodríguez, J.G., Rodriguez-Ezpeleta, N., Smith, C., Stefanova, K., Tempera, F., Vassilopoulou, V., Verissimo, H., Yilmaz, E.C., Zaiko, A., Zenetos, A., 2014. Existing biodiversity, nonindigenous species, food-web and seafloor integrity Gens indicators. Deliverable 3.1, Devotes EU project http://www.devotes-project.eu/wp-content/uploads/2014/02/D3-1_Existingbiodiversity-indicators.pdf

Teixeira, H., Berg, T., Uusitalo, L., Fürhaupter, K., Heiskanen, A.S., Mazik, K., Lynam, C.P., Neville, S., Rodriguez, J., Papadopoulou, N., Moncheva, S., Churilova, T., Kryvenk, 0. Krause-Jensen, D., Zaiko, A. Veríssimo, E., Pantazi, M., Carvalho, S., Patrício, J., Uyarra, M.C., Borja, A., 2016. A Catalogue of marine biodiversity indicators. Front. Mar. Sci., 3, 207. https://doi.org/10.3389/fmars.2016.00207 https://www.frontiersin.org/articles/10.3389/fmars.2016.00207/full

UNEP/MAP, 2017. Integrated Monitoring and Assessment Programme of the Mediterranean Sea and Coast and Related Assessment Criteria. United Nations Environment Programme / Mediterranean Action Plan, Athens, Greece.

Uusitalo, L., Blanchet, H., Andersen, J. H., Beauchard, O., Berg, T. et al. (2016) IndicatorBased Assessment of Marine Biological Diversity-Lessons from 10 Case Studies across the European Seas. Front. Mar. Sci, 3, 159. https://doi.org/10.3389/fmars.2016.00159 https://www.frontiersin.org/articles/10.3389/fmars.2016.00159/full 
Uye, S.I., 1994. Replacement of large copepods by small ones with eutrophication of embayments: cause and consequence. Hydrobiologia, 292: 513-519. https://doi.org/10.1007/BF00229979 https://link.springer.com/article/10.1007/BF00229979

Vadrucci, M. R., E. Stanca, C. Mazziotti, S. F. Umani, G. Assimakopoulou, S. Moncheva, A. Romano, R. Bucci, N. Ungaro \& A. Basset, 2013. Ability of phytoplankton trait sensitivity to highlight anthropogenic pressures in Mediterranean lagoons: A size spectra sensitivity index (ISS-phyto). Ecol. Indic. 34,113-125. https://doi.org/10.1016/j.ecolind.2013.04.013 https://www.sciencedirect.com/science/article/pii/S1470160X13001763

Varkitzi, I., Pagou, K., Granéli, E., Hatzianestis, I., Krasakopoulou, E., Pavlidou, A., 2013. Spatio-temporal distribution of Dinophysis spp. in relation to organic matter availability and other parameters in Thermaikos Gulf, Greece (Eastern Mediterranean), in: Pagou, K., Hallegraeff, G. (Eds.), Proceedings of the 14th International Conference on Harmful Algae, ISSHA and IOC, pp. 51-53. https://issha.org/publications-resources/conference-proceedings/

Varkitzi I, Markogianni V, Pantazi M, Pagou K, Pavlidou A, Dimitriou E. in press Effect of river inputs on environmental status and potentially harmful phytoplankton in a coastal area of eastern Mediterranean (Maliakos Gulf, Greece). Med. Mar. Sci. http://dx.doi.org/10.12681/mms.14591 https://ejournals.epublishing.ekt.gr/index.php/hcmr-med-marsc/article/view/14591

Vershinin, A. O., Moruchkov, A. A., Leighfield, T., Sukhanova, I. N., Pan'kov, S. L., Morton, S. L., Ramsdell, J. S., 2005. Potentially toxic algae in the coastal phytoplankton of the Northeast Black Sea in 2001-2002. Oceanology, 45, 224-232. https://www.researchgate.net/publication/285045889_Potentially_toxic_algae_in_t he_coastal_phytoplankton_of_the_northeast_Black_Sea_in_2001-2002

Vila M., Maso, M. 2005. Phytoplankton functional groups and harmful algal species in anthropogenically impacted waters of the NW Mediterranean Sea. Sci. Mar., 69, 3145. https://doi.org/10.3989/scimar.2005.69n131 http://scientiamarina.revistas.csic.es/index.php/scientiamarina/article/viewArticl $\mathrm{e} / 232$

Williams, P. J. L. B., Quay, P. D., Westberry, T. K., Behrenfeld, M. J., 2013. The oligotrophic ocean is autotrophic. Annu. Rev. Mar. Sci., 5, 535-549. https://doi.org/10.1146/annurev-marine-121211-172335 https://www.annualreviews.org/doi/full/10.1146/annurev-marine-121211172335

Whitman W.B., Coleman D.C., Wiebe W.J., 1998. Prokaryotes: the unseen majority. PNAS, 95, 6578-83. https://doi.org/10.1073/pnas.95.12.6578 http://www.pnas.org/content/95/12/6578

Würtz, M., 2010. Mediterranean Pelagic Habitat: Oceanographic and Biological Processes, an Overview. IUCN, Gland, Switzerland, and Malaga, Spain. http://www.rac-spa.org/sites/default/files/doc_fsd/med_pelagic_habitats.pdf

Zingone A., Siano R., D’alelio D., Sarno, D., 2006. Potentially toxic and harmful microalgae from coastal waters of the Campania region (Tyrrhenian Sea, Mediterranean Sea). Harmful Algae, 5, 321-337. https://doi.org/10.1016/j.hal.2005.09.002 https://www.sciencedirect.com/science/article/pii/S1568988305000892

Zoppini, A., Amalfitano, S., Fazi, S., Tugrul, S., Uysal, Z., Puddu, A., 2010. Carbon flow mediated by microbial communities in the Eastern Mediterranean Sea. Rapp. Comm. Int. Mer Medit. 39, 417.

Zoppini, A., Pettine, M., Totti, C., Puddu, A., Artegiani, A., Pagnotta, R. 1995. Nutrients, standing crop and primary production in the western coastal waters of the Adriatic Sea. Estuar. Coast. Shelf Sci. 41, 493-513. https://doi.org/10.1016/02727714(95)90024-1 
1459 https://www.sciencedirect.com/science/article/pii/0272771495900241

1460 